\title{
Modelling biogeochemical processes in sediments from the north-western Adriatic Sea: response to enhanced particulate organic carbon fluxes
}

\author{
Daniele Brigolin $^{1}$, Christophe Rabouille ${ }^{2}$, Bruno Bombled ${ }^{2}$, Silvia Colla ${ }^{1}$, Salvatrice Vizzini ${ }^{3}$, Roberto Pastres ${ }^{1}$, and \\ Fabio Pranovi ${ }^{1}$ \\ ${ }^{1}$ Department of Environmental Sciences, Informatics and Statistics, Università Ca' Foscari, \\ Venice, 30172, Italy \\ ${ }^{2}$ Laboratoire des Sciences du Climat et de l'Environnement, UMR CEA-CNRS-UVSQ et IPSL, \\ Gif-sur-Yvette, 91198, France \\ ${ }^{3}$ Department of Earth and Marine Sciences, Università degli studi di Palermo, Palermo, 90123, Italy
}

Correspondence: Daniele Brigolin (brigo@unive.it)

Received: 22 May 2017 - Discussion started: 7 June 2017

Revised: 16 January 2018 - Accepted: 2 February 2018 - Published: 5 March 2018

\begin{abstract}
This work presents the result of a study carried out in the north-western Adriatic Sea, by combining two different types of biogeochemical models with field sampling efforts. A longline mussel farm was taken as a local source of perturbation to the natural particulate organic carbon (POC) downward flux. This flux was first quantified by means of a pelagic model of POC deposition coupled to sediment trap data, and its effects on sediment bioirrigation capacity and organic matter (OM) degradation pathways were investigated constraining an early diagenesis model by using original data collected in sediment porewater. The measurements were performed at stations located inside and outside the area affected by mussel farm deposition. Model-predicted POC fluxes showed marked spatial and temporal variability, which was mostly associated with the dynamics of the farming cycle. Sediment trap data at the two sampled stations (inside and outside of the mussel farm) showed average POC background flux of $20.0-24.2 \mathrm{mmol} \mathrm{C} \mathrm{m}^{-2} \mathrm{~d}^{-1}$. The difference of organic carbon (OC) fluxes between the two stations was in agreement with model results, ranging between 3.3 and $14.2 \mathrm{mmol} \mathrm{C} \mathrm{m}^{-2} \mathrm{~d}^{-1}$, and was primarily associated with mussel physiological conditions. Although restricted, these changes in POC fluxes induced visible effects on sediment biogeochemistry. Observed oxygen microprofiles presented a $50 \%$ decrease in oxygen penetration depth (from 2.3 to $1.4 \mathrm{~mm}$ ), accompanied by an increase in the $\mathrm{O}_{2}$ influx at the station below the mussel farm (19-31 versus 10-12 mmol
\end{abstract}

$\mathrm{O}_{2} \mathrm{~m}^{-2} \mathrm{~d}^{-1}$ ) characterised by higher POC flux. Dissolved inorganic carbon (DIC) and $\mathrm{NH}_{4}^{+}$concentrations showed similar behaviour, with a more evident effect of bioirrigation underneath the farm. This was confirmed through constraining the early diagenesis model, of which calibration leads to an estimation of enhanced and shallower bioirrigation underneath the farm: bioirrigation rates of $40 \mathrm{yr}^{-1}$ and irrigation depth of $15 \mathrm{~cm}$ were estimated inside the shellfish deposition footprint versus $20 \mathrm{yr}^{-1}$ and $20 \mathrm{~cm}$ outside. These findings were confirmed by independent data on macrofauna composition collected at the study site. Early diagenesis model results indicated a larger organic matter mineralisation below the mussel farm (11.1 versus $18.7 \mathrm{mmol} \mathrm{m}^{-2} \mathrm{~d}^{-1}$ ), characterised by similar proportions between oxic and anoxic degradation rates at the two stations, with an increase in the absolute values of oxygen consumed by OM degradation and reduced substances re-oxidation underneath the mussel farm.

\section{Introduction}

Disturbance gradients in benthic habitats of marine soft sediment can cause shifts in species behaviours and interactions, thus affecting the biodiversity-ecosystem function relationship (Snelgrove et al., 2014; Villnäs et al., 2013). Disturbance gradients can also affect spatial habitat heterogeneity, determining changes in essential ecosystem traits such as food 
web functioning (Rooney et al., 2008). Mathematical models of early diagenesis - reaction transport models that allow the simulation of organic matter degradation and kinetic and equilibrium reactions, as well as biologically mediated processes, such as bioturbation and bioirrigation (e.g. Arndt et al., 2013) - can represent useful tools to study sediment biogeochemistry and animal-sediment interactions under specific conditions of organic matter deposition and to generalise results from in situ observation and/or lab experiments (Volkenborn et al., 2012). However, their use for studying the effects of disturbance gradients in coastal sediments was very limited in the past (Paraska et al., 2014).

Shellfish farming is regarded as an extractive aquaculture activity (Barrington et al., 2009). However, the production of faeces and pseudofaeces (excess particles rejected by palps before ingestion) leads to a net transfer of organic matter from the water column to the surface sediment (Tenore and Dunstan, 1973; Cranford et al., 2007). This process is expected to locally affect sediment biogeochemistry, benthicpelagic coupling, and benthic community functioning. A range of studies performed in the last 30 years reported on farm-induced changes in sedimentation rates (Callier et al., 2006), sulfate reduction (Dahlbäck and Gunnarson, 1981), $\mathrm{NH}_{4}^{+}$and $\mathrm{PO}_{4}^{2-}$ regeneration (Hatcher et al., 1994; Nizzoli et al., 2005), porewater nutrient concentration gradients (Mesnage et al., 2007), and benthic community structure (StenonDozey et al., 1999; Mirto et al., 2000; Christensen et al., 2003). Only recently has the quantitative understanding of these processes received attention in relation to the assessment of "positive modifications" induced by shellfish farm deposition on benthic habitats (McKindsey et al., 2011). The influence of local hydrodynamics on the fluxes of organic matter deposited by mussel farms was the focus of two modelling studies, by Hartstein and Stevens (2005) and Weise et al. (2009). Based on these works it was possible to have a clearer mechanistic understanding of the relationship between the values of flux and the area affected by organic deposition and the different farming conditions (in terms of local hydrodynamics and farm characteristics - depth and geometry). To the best of our knowledge, less attention has been given to the pelagic-benthic coupling associated with the different phases of the rearing cycle, and, ultimately linked to the physiology of the farmed mussel; faeces and pseudofaeces production rates are dependent on water temperature and seston quantity and quality (Tenore and Dunstan, 1973), parameters which could present remarkable variations on the annual timescale, in particular at those sites characterised by a relatively fast grow-out cycle, e.g. the Mediterranean Sea.

In this work, a longline mussel farm located in the northwestern Adriatic Sea was regarded as a local source of perturbation of natural organic matter downward fluxes. Average yearly increase in particulate organic carbon (POC) flux induced by the mussel farm throughout the year was first quantified by applying a biogeochemical model of POC production and deposition (mussel faeces and pseudofaeces), cou- pled to two sediment trap deployments, which were carried out at the beginning and at the end of mussel farming cycles, with the aim of corroborating model predictions. Outputs of this first model were subsequently used in early diagenesis model simulations (one steady-state and one transient), which were constrained by the observed field data in the sampled cores at two stations (pristine and impacted): bioirrigation parameters and ratio among degradation pathways were estimated on the basis of model application. Measurements included $\mathrm{O}_{2}$ microprofiling, porosity and microporosity, porewater $\mathrm{NH}_{4}^{+}$and $\mathrm{SO}_{4}^{2-}$, and dissolved inorganic carbon (DIC). The objectives of this study are a better understanding of seasonal and inter-annual variability in POC deposition fluxes from the mussel farm and the quantification of benthic recycling of organic matter under contrasted forcings linked to mussel farming, associated ecological mechanisms (bioirrigation), and the relative importance of oxic versus anoxic processes.

\section{Materials and methods}

\subsection{Study site and mussel farm description}

The study was performed at a Mediterranean mussel (Mytilus galloprovincialis) farm located approximately 1.5 nautical miles offshore the city of Jesolo (Italy), in the north-western Adriatic Sea (Fig. 1). The area is characterised by a flat bathymetry, ranging between 13 and $15 \mathrm{~m}$ (Colla, 2017). The farm is affected by the freshwater plume of the Sile River, of which outlet is located at approximately $1.5 \mathrm{~nm}$ distance from the south-western edge of the farm (Fig. 1). The mean annual Sile River discharge in 2008-2009 was $10.9 \mathrm{~m}^{3} \mathrm{~s}^{-1}$, ranging between $5.2 \mathrm{~m}^{3} \mathrm{~s}^{-1}$ in March 2008 and $14.7 \mathrm{~m}^{3} \mathrm{~s}^{-1}$ in December 2009 (ARPAV, 2010). A grain size analysis was recently carried out in the area: sediments were classified as silty-sandy, with percentages of sand and mud respectively within the ranges of $11.9-25.5 \%$ and $88.1-74.5 \%$ (Colla, 2017). Offshore mussel farming is extensively practised in the northern Adriatic Sea, and farmed mussels account for approximately two-thirds of the national Italian production (MiPAAF, 2014). The mussel farm studied covers an area of about $2 \mathrm{~km}^{2}$ and has been operating since 1990 with an average annual production ranging between 600 and $800 \mathrm{tyr}^{-1}$ (Colla, 2017). Mussels are grown on ropes approximately $4 \mathrm{~m}$ long, which are suspended on cables, and are placed at depths between 2 and $4 \mathrm{~m}$. Lines are positioned parallel to the coast, along the principal current direction, at a distance of $40 \mathrm{~m}$ from each other. The length of each line is approximately $2 \mathrm{~km}$. Mussels are normally harvested in JulySeptember, after a rearing cycle lasting a single year, during which they are re-socked 2-3 times (Colla, 2017). 


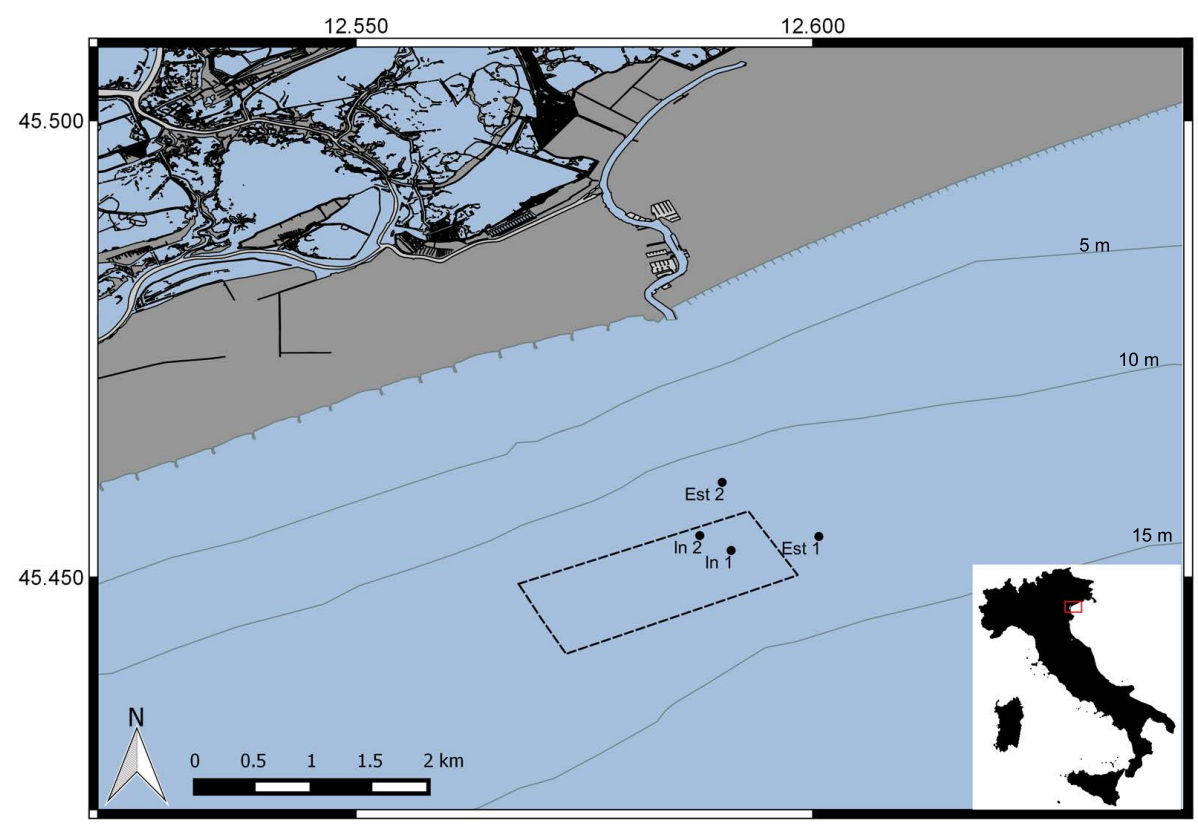

Figure 1. Study site. The dotted rectangle marks the edge of the area in which the mussel farm is located. The Sile River outlet is visible along the coast, northward of the farm area. Stations sampled in this study are marked as black dots (IN1, IN2: under the influence of the farm; EST1, EST2: nearby stations, outside the influence of the farm).

\subsection{Model theory: mussel farm deposition model and early diagenesis model}

For the purposes of this work, the model described by Brigolin et al. (2014) was modified to simulate the C, N, and $\mathrm{P}$ biogeochemical fluxes across shellfish farms. For an introductive description of the model, the reader should refer to the original publication; here we will focus on those changes required to adapt the model to the simulation of mussel farms deposition. The model (Fig. 2) combines two generic modules, respectively accounting for (i) individual growth and dynamics of the farmed population and (ii) organic particle tracking and deposition.

Mussel growth and population dynamics were estimated by means of the individual-based approach by Brigolin et al. (2009). This individual model is capable of simulating physiological processes and their response to key environmental forcings, i.e. suspended particulate matter quality/quantity and water temperature. The individual growth model requires time series of daily values of seawater temperature and concentrations of chlorophyll $a$, POC, and total suspended solids as input. The model allows the daily energy intake, weight gain, and faeces and pseudofaeces production rate to be accounted for, the latter two representing the input for the deposition module. The individual model was upscaled to the population level by means of a set of Monte Carlo simulations, which were used for estimating the size structure of the population (the virtual population was made up of 5000 individuals). In accordance with Bacher and Gangnery (2006) such differences were accounted for by assigning a different maximum clearance rate to each specimen, reflecting variability in individual phenotypes as well as differences in the localisation of specimens within the farm. The model allows farm geometry to be specified based on a set of basic parameters. An interval is selected in order to account for the depth at which ropes are positioned, $z_{f \min }-z_{f \max }$, and the initial position of mussel biodeposits (faeces and pseudofaeces) is assigned randomly within this interval. Longlines - cables on which ropes containing mussels are attached - are disposed parallel each to the other, at a fixed distance, $S_{x}$, and with a defined orientation with respect to the north, $D_{\mathrm{N}}$. Mussels are considered to have an homogeneous density, $B_{i}$, within the same $i$ th longline. A fixed number of longlines, $n_{\mathrm{L}}$, of length $l_{\mathrm{L}}$, are assumed to be productive within a farming cycle. The bathymetry of the farmed area can either be specified through an external file or assumed to be flat. Faeces and pseudofaeces deposition from mussel lines is simulated by means of a Lagrangian technique, consistent with the advection-diffusion equation (details in Jusup et al., 2007). The effect of structures on the current within the farm was not accounted for in the present work, due to the lack of 2-D current meter data required (e.g. the work by Hartstein and Stevens (2005) for New Zealandtype longlines). This model requires time series of water velocity and fluxes of faeces and pseudofaeces as input. The latter two time series are provided by the individual-based population dynamic model with a daily resolution. Fluxes associated with the metabolic activities of the entire farmed population are computed by integrating individual fluxes over the 
size structure of the population, and over time; see Eq. (4) in Brigolin et al. (2014). These fluxes are equally partitioned among $\mathrm{C}, \mathrm{N}$, and $\mathrm{P}$ content to each generic particle. Particles are released homogeneously within $24 \mathrm{~h}$, with a total of 5000 particles launched every day from each mussel line. The output of this module are daily maps of downward fluxes of organic $\mathrm{C}, \mathrm{N}$, and $\mathrm{P}$ reaching the sea bed (in $\mathrm{g} \mathrm{m}^{-2} \mathrm{~d}^{-1}$ ). The complete set of parameters used in the deposition model and their values and references are reported in Table A1 (Appendix). Settling velocities for mussel faeces and pseudofaeces were set to $1.0 \pm 0.1$ and $0.1 \pm 0.01 \mathrm{~cm} \mathrm{~s}^{-1}$ (Weise et al., 2009; Chamberlain, 2002). The settling velocity of each particle was randomly selected from a Gaussian distribution.

The early diagenesis model (EDM) was developed by means of the Biogeochemical Reaction Network Simulator (BRNS) (Regnier et al., 2002) through a knowledgebased reactive transport model application (Aguilera et al., 2005). In the present application we used a simplified version of the EDM identified for the northern Adriatic Sea by Brigolin et al. (2011). The model solves the diagenetic equations describing mass conservation for solids and dissolved species in a vertical sediment column; see Eqs. (1) and (2) in Table A2 (Berner, 1980; Boudreau, 1997). The advection term includes burial, compaction, and bioirrigation; the diffusion term includes molecular and ionic diffusion, as well as bioturbation. Non-local mixing due to bioirrigation has been previously included in models developed using the BRNS (e.g. Dale et al., 2008), and in the present application we assumed a profile for the bioirrigation rate of the type reported by Canavan et al. (2006) for a coastal lake (formulation reported in Table 2). Organic matter oxidation is described by means of a multi-G model (Westrich and Berner, 1984) with three types of organic matter: labile (OM1), semi-refractory (OM2), and mussel biodeposits (faeces + pseudofaeces) (OM3), following the approach by Van Cappellen and Wang (1996). Oxic and anoxic pathways of organic matter oxidation, as well as secondary redox reactions, are included (Table A2). As said, the reaction network is simpler with respect to the one published in Brigolin et al. (2011), not including reactions involving $\mathrm{Fe}$ and $\mathrm{Mn}$, of which processes were not the focus of the present work. According to Burdige (2006), in shallow depth environments, $\mathrm{Fe}$ and $\mathrm{Mn}$ contribute on average $10 \%$ of the total mineralisation, with peaks around $20 \%$; this latter value is also in agreement with the estimations by Van Cappellen and Wang (1996). A fixed concentration was imposed at the upper boundary for all solutes, while a fixed flux was used for solids. The model was coded in Fortran. The ordinary differential equations were integrated numerically by means of a fourth-order Runge-Kutta scheme (Press et al., 1987). The Lagrangian equation for the deposition model was solved following Jusup et al. (2007). The set of partial differential equations in the EDM was numerically solved by means of an implicit method; details on the operator splitting technique - a sequential non-iterative approach
- and the definition of the function residuals and the Jacobian matrix are provided in Aguilera et al. (2005) and Regnier et al. (2002). Model runs were performed in SCSCF (www.dais.unive.it/scscf), a multiprocessor cluster system owned by Ca' Foscari University of Venice running under GNU/Linux.

\subsection{Model application: simulation setup and EDM calibration}

Based on the rearing cycle characteristics, described in Sect. 2.1, in model simulations shellfish are stocked in September, and harvested after 1 year. The farm, made up of $n_{\mathrm{L}}=25$ longlines of length $l_{\mathrm{L}}=2000 \mathrm{~m}$ each, occupies a total area of $2 \times 1 \mathrm{~km}^{2}$. The longlines' orientation with respect to north, $D_{\mathrm{N}}$, was $60^{\circ}$. A density, $B_{i}=15$ ind. $\mathrm{m}^{-2}$, was considered at all the longlines of the farm. A depth range, $z_{f \min }-z_{f \max }$, of between 1 and $7 \mathrm{~m}$ was selected as representative of ropes at the farm considered in this study. The model application aimed to constrain the typical variability of mussel deposition at the farm site. In order to simulate the average flux of POC deposited by the farm, we carried out 10 different runs, considering each one a rearing cycle under forcings for a different year within the 2002-2011 time frame. Satellite data were used as inputs for the individualbased population dynamic model, in accordance with previous studies (e.g. Thomas et al., 2011; Filgueira et al., 2013). The median daily value of faeces and pseudofaeces fluxes from the 10 simulations was used as an input for the deposition model. In computing these statistics we followed an approach similar to the one reported by Sarà et al. (2013), in order to smooth potential biases introduced in the model through the forcing data. This precaution was adopted since northern Adriatic optically shallow waters are influenced by river discharge, and chlorophyll $a$ concentrations could be potentially overestimated in specific months due to the interference caused by coloured dissolved organic matter absorbance (Cannizzaro and Carder, 2006). Our choice to rely on satellite-derived chlorophyll $a$ concentrations was supported by two main considerations.

- The analysis by Mauri et al. (2007) reported very weak correlations between Po River discharge and interpolated satellite-derived chlorophyll $a$ concentrations in the area of interested to this study, and the Sile River does not provide perturbation of water clarity except during major floods (average runoff of the Sile River is approximately 1 order of magnitude lower than Adige and Brenta and 2 orders lower than Po; Cozzi and Giani, 2011).

- The median values of chlorophyll $a$ concentrations obtained from satellite data (see description below and Fig. A1) were compatible with the median values reported by Solidoro et al. (2009) based on the analysis of 20 years of data (1986-2006) of in situ chlorophyll $a$ 


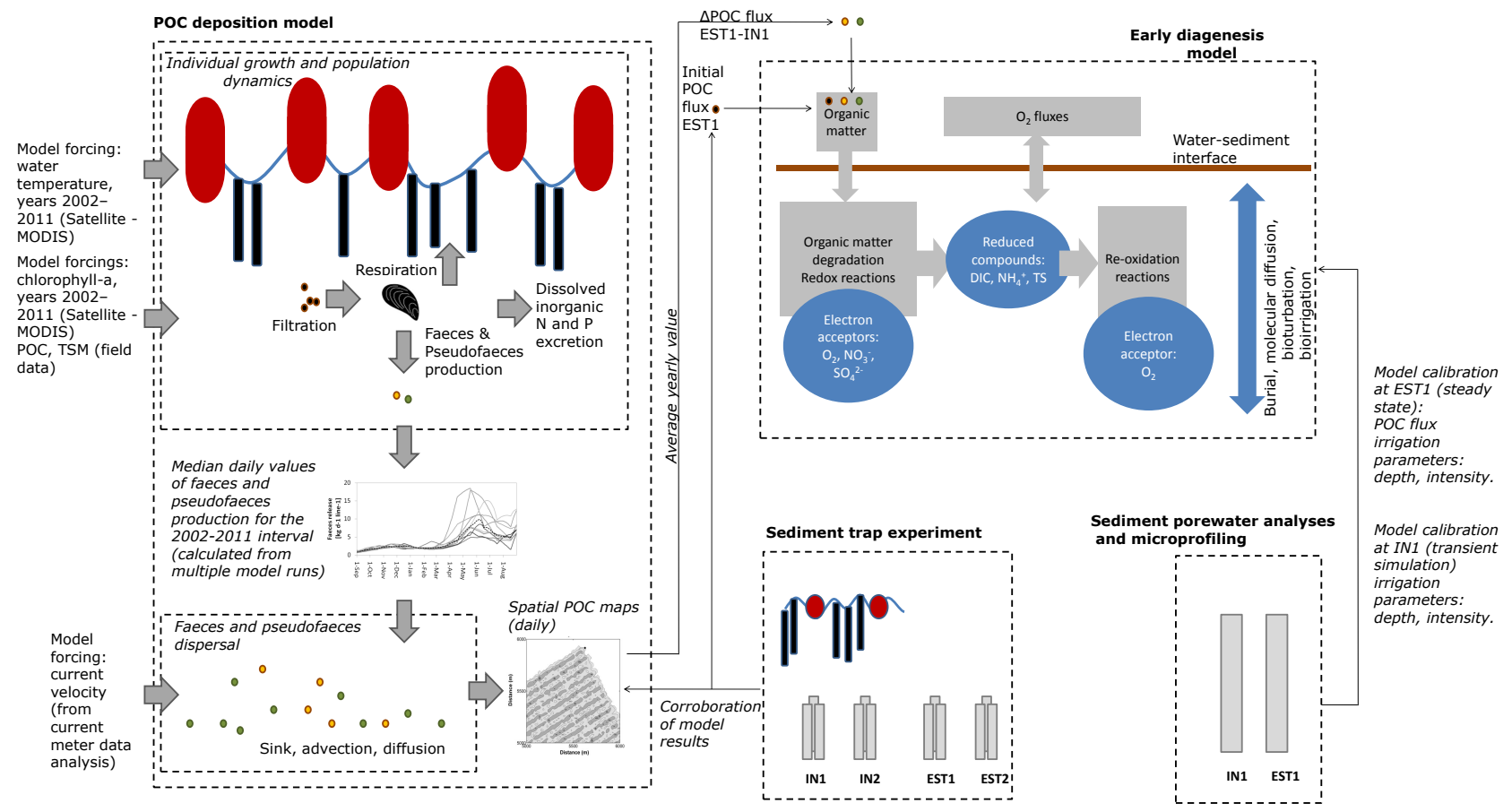

Figure 2. Information flow within this study. The typical structure of a longline mussel farm is schematically represented in the upper-left part of the figure: cables (blue lines) are attached to floating buoys (red areas) and ropes (black rectangles), on which mussels are stocked. Black particles (small circles) represent the background POC flux, while green and orange particles stand for mussel faeces and pseudofaeces. Sediment traps (in triplicate) are represented as small grey rectangles, while larger rectangles on the right-hand side of the figure represent the sediment cores.

measurements, for a portion of sea which included our study area (referred as sector 3 in their work), ranging between 1.35 and $2.38 \mu \mathrm{g} \mathrm{L}^{-1}$ in the upper layer $(0-$ $7.5 \mathrm{~m})$.

Time series of monthly sea surface temperature and concentration of chlorophyll $a$ were extracted from the EMIS (http://emis.jrc.ec.europa.eu/) database from July 2002 to December 2012, (long $\min 12.5$; long $\max 12.6$; lat $\min 45.4$; lat max 45.5) by means of the R package EMISR v0.1 (R version 3.0.3). Chlorophyll $a$ concentrations and sea surface temperature data were derived from MODIS (Moderate Resolution Imaging Spectroradiometer) Aqua and Terra satellites respectively, with a spatial resolution of $4 \mathrm{~km}$. Being the farm located at the intersection of 4 pixels, in an area characterised by a flat bathymetry, it was considered more representative to take the concentration as an average among the 4 pixels, rather than selecting a single value. Due to the lack of long-term time series of data, an average POC concentration had to be imposed, $0.1 \mathrm{mg} \mathrm{L}^{-1}$, on the basis of a time series of monthly data collected at a nearby farm between 2006 and 2007 (Brigolin et al., 2009). The particulate organic matter/total suspended solids ratio was fixed on the basis of the time series collected within the same work (Brigolin et al., 2009), providing an average absorption efficiency of 0.6.
Modelling deposition requires time series of water velocity at an hourly time step as input. These data were provided on the basis of a current meter deployment carried out between March and September 2010 at a station located approximately $500 \mathrm{~m}$ from the northeastern edge of the farm (Alfredo Boldrin, personal communication, 2014; Fig. A2 in Appendix). Current meter data were first processed by means of a classical harmonic analysis, in order to extract tidal components as well as long-term residual means (Pawlowicz et al., 2002). On the basis of the procedure proposed by Jusup et al. (2007), the residual currents were therefore edited randomly for short periods of time in order to reproduce the variability recorded from current meter measurements during extreme events (i.e. storms). The number of events was imposed on the basis of the 2010 current time series and of previous current meter deployments available for this area (Rampazzo et al., 2013; Giovanardi et al., 2003). The effects of tide and storm events were therefore accounted for in the final time series, while short-term fluctuations related to turbulence were accounted for by the deposition model, as reported by Jusup et al. (2007).

A steady-state EDM simulation was carried out at station EST1 located outside of the mussel farm. The model was applied by using the same parameterisation adopted for the north-western Adriatic shelf by Brigolin et al. (2011) (see Tables A3-A4) and by calibrating the POC downward flux, 

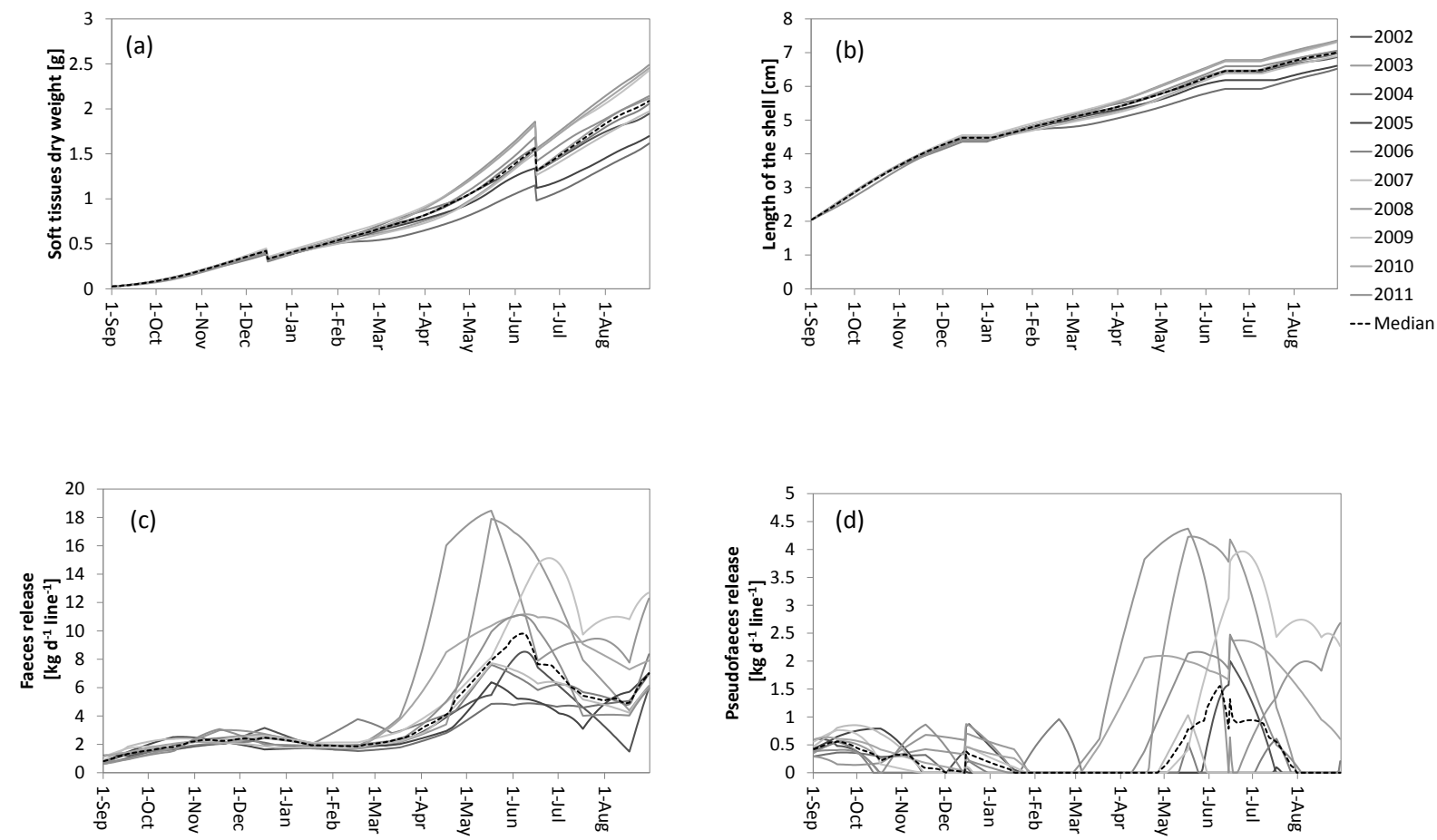

Figure 3. (a, b) Mussel soft tissues' dry weight and shell length; (c, d) faeces and pseudofaeces release fluxes per mussel line per day. Results of 10 different model runs and the overall medians are reported (years 2002-2011). Forcings provided as input to the model are presented in Fig. A1. Discontinuities in (a) represent weight losses due to spawning events (model theory in Brigolin et al., 2009).

$\Phi_{\mathrm{OM} 1+\mathrm{OM} 2}$, and the parameters, $\alpha_{0}$ and $x_{\mathrm{irr} 1}$, defining intensity and depth of bioirrigation, respectively. Initial values of POC downward flux for the calibration were set on the basis of the results of the sediment trap experiment (see Sect. 2.4 below). This steady-state model calibration was carried out by fitting the $\mathrm{O}_{2}, \mathrm{DIC}, \mathrm{NH}_{4}^{+}$, and $\mathrm{SO}_{4}^{2-}$ profiles observed at station EST1. The transient simulation carried out at station IN1 was performed by imposing model outputs obtained at station EST1 as initial conditions. The model, which had the same structure of the EDM run at EST1, was run for 20 years (time of activity of the farm) by taking into account the average $\mathrm{OM}_{3}$ flux (faeces + pseudofaeces) predicted by the deposition model at station IN1. The $\alpha_{0}$ and $x_{\text {irr1 }}$ parameters were calibrated by fitting the $\mathrm{O}_{2}$, DIC, $\mathrm{NH}_{4}^{+}$, and $\mathrm{SO}_{4}^{2-}$ profiles observed at station IN1. Diffusive oxygen uptake was calculated from profiles (both model and data; see Sect. 2.5 below) by means of the 1-D Fick's first law of diffusion. These fluxes were assessed from oxygen profiles by considering the oxygen gradient within the thin diffusive boundary layer. Temperature and salinity corrections were accounted for, based on measurements performed on bottom water samples. Porosity was taken into account, and the calculation of the diffusion coefficients was done in accordance with Andrews and Benett (1981).

\subsection{Sediment traps measurements}

As part of this study, sedimentation fluxes were measured by means of sediment traps positioned at the bottom. Two $48 \mathrm{~h}$ sediment trap deployments were carried out. The first experiment was performed between 29 and 31 August 2014, at the end of the annual mussel rearing cycle. The second was carried out between 11 and 13 September 2015, at the very beginning of the annual mussel rearing cycle. Three PVC (polyvinyl chloride) sediment traps were deployed at each station, with a cylindrical shape, an aspect ratio of $5: 1$, and a collecting area of $0.0095 \mathrm{~m}^{2}$ each (Cromey et al., 2002; Jusup et al., 2009). In the first experiment (Fig. 1), sediment traps were deployed at four locations; two stations, IN1 and IN2, located inside the modelled depositional footprint, and two stations outside, EST1 and EST2. For the second experiment, one station was located inside, IN1, and one outside, EST1. Upon collection traps content was filtered through pre-combusted $\left(450{ }^{\circ} \mathrm{C}, 4 \mathrm{~h}\right)$ and pre-weighed Whatmann GF/F filters. For total mass flux determination, filters were dried at $60^{\circ} \mathrm{C}$ for $24 \mathrm{~h}$ and re-weighed. For POC determination, filters were stored at $-20^{\circ} \mathrm{C}$ until analysis, which was carried out by means of a Thermo Elemental Analyzer (Flash - EA 1112), after acidification with $\mathrm{HCl}$ for removing carbonates. The percentage of organic carbon on total mass $(\mathrm{OC} \%$ ) was calculated from POC fluxes and total mass fluxes. 

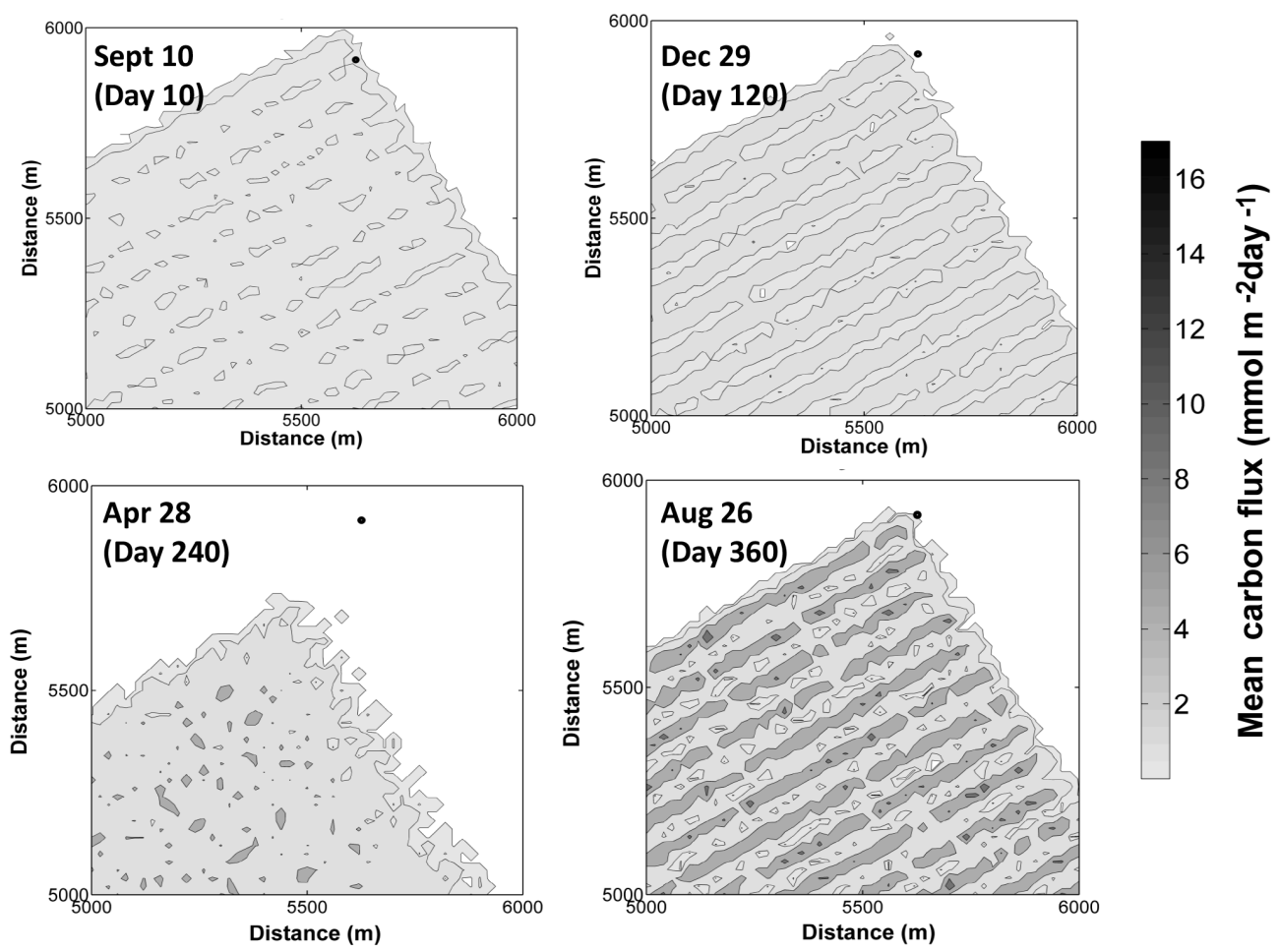

Figure 4. Model predicted fluxes of organic C reaching the sediment at simulation days 10 (10 September), 120 (29 December), 240 (28 April), and 360 (26 August). The black dot marks the north-eastern edge of the farmed area (see farm representation in Fig. 1).

\subsection{Sediment coring, microelectrode measurements, porewater, and solid-phase analyses}

Sediments were sampled at stations IN1 and EST1 in June 2015 (on 23 and 24 June). Undisturbed cores were collected by means of an Uwitec corer $(10 \mathrm{~cm}$ diameter; $20 \mathrm{~cm}$ average penetration depth). Water was sampled $2 \mathrm{~m}$ above the bottom by means of a Niskin bottle, for dissolved oxygen, salinity, and temperature determinations. Cores were immediately brought back to the field camp and prepared for microprofiling, which was conducted a few hours after coring. As the temperature of the outside air was within a few degrees of the water temperature during the cloudy sampling days $\left(23^{\circ} \mathrm{C}\right.$ in air versus $21^{\circ} \mathrm{C}$ in the water), the temperature was not controlled using the available cryostat, but it was monitored at the start and end of the measurements and showed minimal variation. Cores were bubbled with air during measurements to allow aeration and gentle stirring. As the bottom waters were saturated with oxygen, bubbling maintained the proper in situ $\mathrm{O}_{2}$ conditions. Microprofiling was conducted with a Unisense motorised microprofiler. Four oxygen microprofiles were performed using $100 \mu \mathrm{m}$ tip microsensors which were calibrated by a twopoint method: Winkler titration of the overlying water (with a precision of $2 \%$ ) and zero-oxygen signal in the anoxic layer below the oxic zone. Porosity was obtained by measuring the weight loss upon drying at $60^{\circ} \mathrm{C}$, until constant weight. Porosity was recalculated from this weight loss using salt correction and dry bulk density. Porewater was extracted within $4 \mathrm{~h}$ after coring in a glove bag under $\mathrm{N}_{2}$ using Rhizons ${ }^{\circledR}$ (Seeberg-Elverfeldt et al., 2005). Samples were preserved using $\mathrm{HgCl}_{2}$ saturated for DIC and total alkalinity (TA) analysis, by freezing for $\mathrm{NH}_{4}^{+}$determination and by acidifying for $\mathrm{SO}_{4}^{2-}$ analysis. Measurements were performed in the laboratory: DIC was analysed in a DIC analyzer (Apollo SciTech ${ }^{\circledR}$ ) using a $1 \mathrm{~mL}$ sample volume, with four to six replicates which provided a standard deviation of $0.5 \%$. TA concentrations were measured in a potentiometric open-cell titration in a $3 \mathrm{~mL}$ sample volume (Rassmann et al., 2016) with an uncertainty of $0.5 \%$. Ammonium concentration was measured spectrophotometrically following Grasshof et al. (1983) with an uncertainty of about $5 \%$. Sulfate was measured using HPLC (high-performance liquid chromatography) in a Dionex Ion Chromatography System (ICS 1000) using a Dionex IonPac AS9-HC Carbonate Eluent Anion-Exchange Column $(4 \times 50 \mathrm{~mm})$ and a Dionex IonPac AG9-HC Guard Column $(4 \times 50 \mathrm{~mm})$ with an uncertainty of $1 \%$. 


\section{Results}

\subsection{POC reaching the sediment-water interface: model simulation results and sediment trap experiments}

Results obtained by means of the population dynamic model are reported in Fig. 3a-d. The time series of satellite data, sea surface temperature, and chlorophyll $a$ concentration used to force the model are shown in Fig. A1. Growth trajectories, expressed here in terms of soft tissues' dry weight and shell length, are in agreement with previous observations and model results obtained for this area (Brigolin et al., 2009). The minimum commercial size of $5 \mathrm{~cm}$ is achieved rapidly ( $<6$ months), and the mussels reach the final length of $7 \mathrm{~cm}$ within 10-11 months. At the end of the cycle mussels present weights between 1.5 and $2.5 \mathrm{~g}$. Total faeces and pseudofaeces release rates per line are shown in Fig. 3c, d. These fluxes are highly variable, both on seasonal (average coefficient of variation $(\mathrm{CV})$ within year for faeces $=0.67$; pseudofaeces $=1.47$ ) and inter-annual timescales (average among years $\mathrm{CV}$ faeces $=0.30$; pseudofaeces $=1.46$ ).

Figure 4 shows the map of the model-predicted fluxes of organic $\mathrm{C}$ induced by the mussels reaching the sediment at days $10,120,240$, and 360 of simulation (10 September; 29 December; 28 April; 26 August). As can be seen, the magnitude of the fluxes increases with mussel growth. Maximum organic carbon fluxes predicted at day 10 and 360, representative of the situation at the beginning and at the end of the growth-out cycle, are 2.5 and $13.3 \mathrm{mmol} \mathrm{C} \mathrm{m}^{-2} \mathrm{~d}^{-1}$, respectively. The footprint induced by the presence of the lines is clearly visible at days 120 and 360. At day 240, a remarkable displacement of deposition towards southwest (approximately $200 \mathrm{~m}$ ) was detected. In the other cases (Fig. 4a, b, d), the maximum footprint distance from the edge of the farm is $50 \mathrm{~m}$.

Total mass fluxes, POC fluxes, and OC \%, measured in $\mathrm{Au}-$ gust 2014 and September 2015 are reported in Table 1. In August 2014, POC fluxes at the end of the rearing cycle showed significantly higher values in stations IN1 and IN2 than in EST1 and EST2 (Mann-Whitney one-tailed; $n 1=6, n 2=6$; $p=0.03$ ), while differences among IN1 and EST1 detected in September 2015 at the beginning of the rearing cycle were on the order of $3.3 \mathrm{mmol} \mathrm{C} \mathrm{m}^{-2} \mathrm{~d}^{-1}$ and not significant (Mann-Whitney two-tailed; $n 1=3, n 2=3 ; p>0.5$ ).

\subsection{Early diagenesis processes underneath the farm and at a nearby station located outside the farm influence}

Bottom water temperature and salinity were respectively $22^{\circ} \mathrm{C}$ and 36.3 psu at both stations. Oxygen in bottom waters, measured through Winkler titration, was $223.5 \pm 0.3 \mu \mathrm{M}$ at EST1 and $229.8 \pm 0.1 \mu \mathrm{M}$ at IN1. The grain size analysis classified sediments as medium silt at EST1 and very fine sandy-coarse silt at IN1. Porosity profiles (Fig. 5a) show a decreasing trend going down-core, with a steep gradient in the upper $20 \mathrm{~mm}$. A discontinuity is visible in the IN1 core, between 40 and $50 \mathrm{~mm}$. A total of seven oxygen profiles were collected at the two stations (Fig. 5b). Oxygen shows a quasimonotonous decrease in concentration downward in the sediment. A slight increase at the interface $(\sim 20 \mu \mathrm{M})$, most probably due to microphytobenthic production, is visible at station EST1 (bubbles were visible on the core surface after long-term exposure to sunlight). Indeed, results obtained at the two stations suggested a limited variability in the oxygen behaviour within the same core - profiles were measured by randomly sampling the available portion of the core in which no shell debris and macrobenthos were visible at the surface. Oxygen is consumed within the first millimetre, showing a higher penetration depth at EST1 (2.3 mm on average) with respect to IN1 (1.4 mm on average). DIC, $\mathrm{NH}_{4}^{+}$, and $\mathrm{SO}_{4}^{2-}$ data are shown in Fig. 5c-e. DIC concentration profiles at the two stations are comparable, although at depths $>10 \mathrm{~cm}$ they stabilise at values around $3.6 \mathrm{mM}$ at EST1 and $2.8 \mathrm{mM}$ at IN1. A similar pattern is visible for ammonium, of which average concentration below $10 \mathrm{~cm}$ depth reaches values of $50 \mu \mathrm{M}$ at IN1 and $125 \mu \mathrm{M}$ at EST1. The effect of bioirrigation is visible within the upper $10 \mathrm{~cm}$, and, is particularly marked at station IN1, where DIC shows a decrease in concentration starting from a depth of $4 \mathrm{~cm} . \mathrm{SO}_{4}^{2-}$ concentrations are similar between the two stations and do not present marked variations going down-core.

Model-predicted profiles (EDM) calibration are given in Fig. 6 and are compared with the measured $\mathrm{O}_{2}$, DIC, $\mathrm{NH}_{4}^{+}$ and $\mathrm{SO}_{4}^{2-}$ field data. Porosity parameters used in the model, and given in Table 2, were estimated by independently fitting the two porosity profiles shown in Fig. 5a. A metabolisable OC flux of $11.6 \mathrm{mmol} \mathrm{C} \mathrm{m}^{-2} \mathrm{~d}^{-1}$ was estimated by calibrating the model at a steady state at station EST1. At IN1, an additional flux of labile organic matter $\left(8.2 \mathrm{mmol} \mathrm{C} \mathrm{m}^{-2} \mathrm{~d}^{-1}\right)$ was imposed for 20 years, based on the median value predicted for POC flux by the pelagic deposition model. In the EDM, DIC and $\mathrm{NH}_{4}^{+}$profiles are both characterised by a concentration enhancement within the first centimetre, controlled by the degradation of the labile organic matter (OM1 and OM3) and subsequently modulated by the action of bioirrigation, which causes a down-core decrease. In general, simulated profiles reasonably agree with observed concentration values, although differences between model and data vertical trends are visible, in particular at station EST1, where predicted $\mathrm{NH}_{4}^{+}$exceeds observed concentrations. The depth distributions of bioirrigation coefficients were estimated independently at the two stations, obtaining values reported in Table 2, which indicate that infauna activity is higher and more concentrated in the superficial layer at IN1 than at EST1. Figure 7 compares these fluxes to the ones estimated by means of microelectrode profiles at the same stations. As can be seen, model results are in good agreement with the ones calculated from micro-electrode profiles. Oxy- 
Table 1. Downward fluxes measured by sediment traps at stations IN1 and IN2 (under the influence of the farm) and EST1 and EST2 (nearby stations, outside the influence of the farm) in August 2014 and September 2015.

\begin{tabular}{lrr|rr|rr}
\hline & \multicolumn{2}{c}{ Total mass flux $\left(\mathrm{g} \mathrm{m}^{-2} \mathrm{~d}^{-1}\right)$} & POC flux $\left(\mathrm{mmol} \mathrm{C} \mathrm{m}^{-2} \mathrm{~d}^{-1}\right)$ & OC \% (\%) \\
\hline Experiment & $\begin{array}{r}\text { Aug 2014 } \\
\text { (end of } \\
\text { rearing cycle) }\end{array}$ & $\begin{array}{r}\text { Sep 2015 } \\
\text { (beginning } \\
\text { of rearing cycle) }\end{array}$ & Aug 2014 & Sep 2015 & Aug 2014 & Sep 2015 \\
\hline IN1 & $6.5 \pm 1.6$ & $5.7 \pm 0.6$ & $34.2 \pm 13.3$ & $27.5 \pm 4.2$ & $6.2 \pm 1.2$ & $5.9 \pm 0.3$ \\
EST1 & $4.6 \pm 0.6$ & $6.9 \pm 1.4$ & $20.0 \pm 5.0$ & $24.2 \pm 5.0$ & $5.2 \pm 0.7$ & $4.2 \pm 0.2$ \\
IN2 & $5.9 \pm 1.6$ & & $32.5 \pm 14.2$ & & $6.3 \pm 1.1$ & \\
EST2 & $4.6 \pm 0.7$ & $20.8 \pm 5.0$ & & $5.5 \pm 0.7$ \\
Difference IN1-EST1 & & $14.2(p=0.03)$ & $3.3(p>0.5)$ & \\
\hline
\end{tabular}

(a)

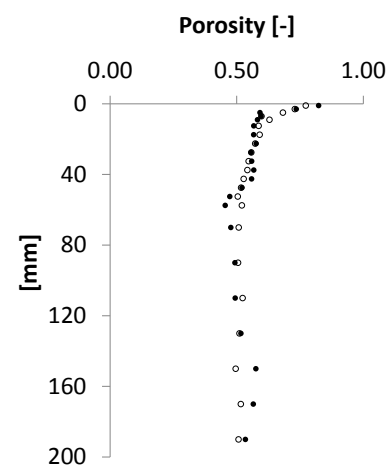

(b)

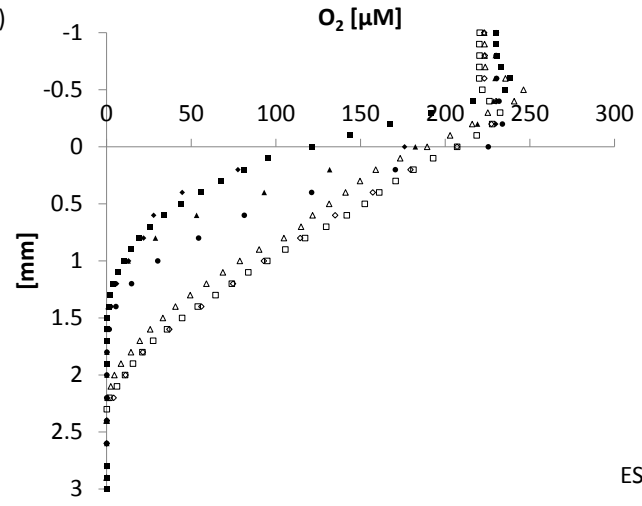

(c)

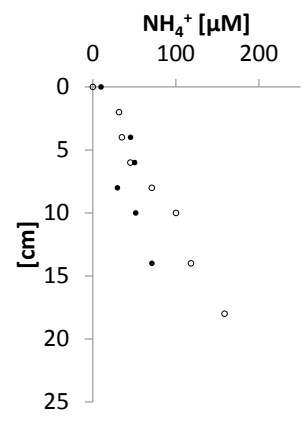

(d)

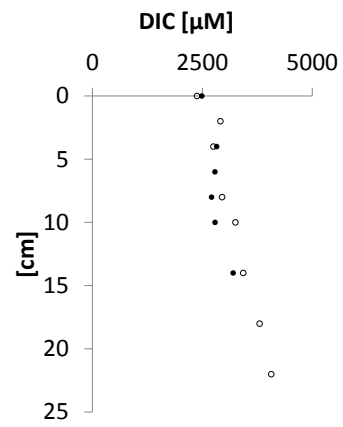

(e)

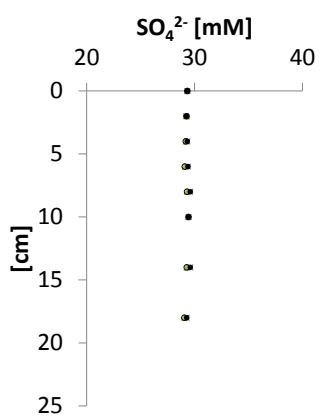

Figure 5. Measured profiles and microprofiles. All $y$ axes refer to vertical depth in the sediment, with 0 set at the sediment-water interface. Panel (a) shows sediment porosity (-). Panel (b) shows dissolved oxygen concentration, marked by squares; triangles, diamonds, and circles represent different microprofiles; black represents IN1; white represents EST1. Panel (c) shows $\mathrm{NH}_{4}^{+}$concentration ( $\left.\mu \mathrm{M}\right)$; $(\mathbf{d})$ dissolved inorganic C concentration (DIC) $(\mu \mathrm{M})$; (e) $\mathrm{SO}_{4}^{2-}$ concentration $(\mathrm{mM})$.

gen fluxes predicted by the model profiles are, respectively, 11 and $18 \mathrm{mmol} \mathrm{O}_{2} \mathrm{~m}^{-2} \mathrm{~d}^{-1}$ at EST1 and IN1, while microelectrode fluxes range between 10 and $12 \mathrm{mmol} \mathrm{O}_{2} \mathrm{~m}^{-2} \mathrm{~d}^{-1}$ at EST1 and 19 and 31 at IN1.

Total mineralisation calculated by the model is $11.1 \mathrm{mmol} \mathrm{C} \mathrm{m} \mathrm{d}^{-1}$ at EST1 and $18.7 \mathrm{mmol} \mathrm{C} \mathrm{m}^{-2} \mathrm{~d}^{-1}$ at IN1 (Table 2). Figure 8 shows the partitioning among mineralisation pathways, indicated by the electron acceptors, of the total organic matter. At EST1, approximately $27 \%$ of the total $\mathrm{OM}\left(3.0 \mathrm{mmol} \mathrm{C} \mathrm{m}^{-2} \mathrm{~d}^{-1}\right)$ undergoes oxic degradation, a fraction similar to that observed at IN1 (30\%), where the total OM flux and also the bioirrigation rate are higher. As reported in Fig. 8, $42 \%$ of the oxygen is consumed at EST1 by organic matter mineralisation, and the remaining $59 \%$ is required for re-oxidising reduced compounds $(55 \%$ by reduced compounds' oxidation and $3 \%$ by nitrification). At IN $1,51 \%$ of the $\mathrm{O}_{2}$ is consumed by 
Table 2. Early diagenesis model (EDM): calibration results and model features at the two stations studied. $\mathrm{OM}_{1}$ refers to fast-degrading $\mathrm{POC} ; \mathrm{OM}_{2}$ refers to slow-degrading POC; $\mathrm{OM}_{3}$ refers to mussel faeces and pseudofaeces.

\begin{tabular}{|c|c|}
\hline $\begin{array}{l}\text { Station EST1 (steady-state) } \\
\text { (outside the influence of the farm) }\end{array}$ & $\begin{array}{l}\text { Station IN1 (transient, 20-year run) } \\
\text { (under the influence of the farm) }\end{array}$ \\
\hline $\begin{array}{l}\text { POC deposition: } \\
11.6 \mathrm{mmol} \mathrm{C}^{-2} \mathrm{~d}^{-1}(\mathrm{OM} 1+\mathrm{OM} 2) \text { calibrated }\end{array}$ & $\begin{array}{l}\text { POC deposition: } \\
11.6 \mathrm{mmol} \mathrm{C} \mathrm{m}^{-2} \mathrm{~d}^{-1}(\mathrm{OM} 1+\mathrm{OM} 2) \\
\text { Based on calibration performed at EST1 } \\
8.2 \mathrm{mmol} \mathrm{C} \mathrm{m}^{-2} \mathrm{~d}^{-1}(\mathrm{OM} 3) \\
\text { Average yearly value predicted by the deposition model at IN1 }\end{array}$ \\
\hline $\begin{array}{l}60 \% \text { fast-degrading }\left(10 \mathrm{yr}^{-1}\right) ; 40 \% \text { slow-degrading } \\
\left(0.01 \mathrm{yr}^{-1}\right) \\
\frac{\mathrm{OM}_{1}}{\left(\mathrm{OM}_{1}+\mathrm{OM}_{2}\right)}=0.6\end{array}$ & $\begin{array}{l}38 \% \text { faeces }\left(20 \mathrm{yr}^{-1}\right) ; 37 \% \text { fast-degrading }\left(10 \mathrm{yr}^{-1}\right) \\
25 \% \text { slow-degrading }\left(0.01 \mathrm{yr}^{-1}\right) \\
\frac{\mathrm{OM}_{1}}{\left(\mathrm{OM}_{1}+\mathrm{OM}_{2}\right)}=0.6\end{array}$ \\
\hline $\begin{array}{l}\text { Bioirrigation rate (see profile in Fig. A3 - black colour): } \\
\alpha_{0}=20 \mathrm{yr}^{-1} \text { (bioirrigation rate at the interface) calibrated } \\
\mathrm{x}_{\mathrm{irr} 1}=20 \mathrm{~cm} \text { (depth of the bioirr. layer) calibrated } \\
\lambda_{1}=0.1 \mathrm{~cm} \text { (shape coefficient) fixed a priori } \\
\alpha(z)=\alpha_{0} \cdot \frac{e^{\left(\frac{x_{\text {irr }}-z}{\lambda_{1}}\right)}}{\left[1+e^{\left(\frac{x_{\text {irr1 }}-z}{\lambda_{1}}\right)}\right]}\end{array}$ & $\begin{array}{l}\text { Bioirrigation rate (see profile in Fig. A3 - grey colour): } \\
\alpha_{0}=40 \mathrm{yr}^{-1} \text { (bioirrigation rate at the interface) calibrated } \\
\mathrm{x}_{\text {irr1 }}=15 \mathrm{~cm} \text { (depth of the bioirr. layer) calibrated } \\
\lambda_{1}=0.1 \mathrm{~cm} \text { (shape coefficient) fixed a priori } \\
\alpha(z)=\alpha_{0} \cdot \frac{e^{\left(\frac{x_{\text {irr1 } 1}-z}{\lambda_{1}}\right)}}{\left[1+e^{\left(\frac{x_{\text {irr1 }}-z}{\lambda_{1}}\right)}\right]}\end{array}$ \\
\hline $\begin{array}{l}\text { Bioturbation rate: } \\
D b_{0}=1.0 \mathrm{~cm}^{2} \mathrm{yr}^{-1} ; \lambda_{2}=1.5 \mathrm{~cm} \text { (Mugnai et al., 2003) } \\
D b(z)=D b_{0} \cdot e^{\left(-z / \lambda_{2}\right)}\end{array}$ & $\begin{array}{l}\text { Bioturbation rate: } \\
D b_{0}=1.0 \mathrm{~cm}^{2} \mathrm{yr}^{-1} ; \lambda_{2}=1.5 \mathrm{~cm} \text { (Mugnai et al., 2003) } \\
D b(z)=D b_{0} \cdot e^{\left(-z / \lambda_{2}\right)}\end{array}$ \\
\hline $\mathrm{C}: \mathrm{N}: \mathrm{P} 129: 18: 1$ (Brigolin et al., 2009) & $\mathrm{C}: \mathrm{N}: \mathrm{P} 129: 18: 1$ (Brigolin et al., 2009) \\
\hline $\begin{array}{l}\text { Porosity parameters } \varphi(z)=\varphi_{\infty}+\left(\varphi_{0}-\varphi_{\infty}\right) e^{-\tau z} \\
\varphi_{0}=0.77 ; \varphi_{\infty}=0.51 ; \tau=0.65\end{array}$ & $\begin{array}{l}\text { Porosity parameters } \varphi(z)=\varphi_{\infty}+\left(\varphi_{0}-\varphi_{\infty}\right) e^{-\tau z} \\
\varphi_{0}=0.82 ; \varphi_{\infty}=0.53 ; \tau=0.1\end{array}$ \\
\hline $\begin{array}{l}\text { Physico-chemical parameters and boundary conditions } \\
T=10^{\circ} \mathrm{C} \text { (yearly average) } \\
S=36.3 \mathrm{PSU} \text { (measurements st. EST } 1) \\
{\left[\mathrm{O}_{2}\right]=223.5 \mu \mathrm{M} \text { (measurements st. EST } 1 \text { ) }} \\
{\left[\mathrm{NH}_{4}^{+}\right]=1.0 \mu \mathrm{M} \text { (measurements st. EST } 1 \text { ) }} \\
\left.\left[\mathrm{NO}_{3}^{-}\right]=2.5 \mu \mathrm{M} \text { (Solidoro et al., } 2009\right) \\
\left.\left[\mathrm{SO}_{4}^{2-}\right]=28.7 \mathrm{mM} \text { (measurements st. EST }\right)\end{array}$ & $\begin{array}{l}\text { Physico-chemical parameters and boundary conditions } \\
T=10^{\circ} \mathrm{C} \text { (yearly average) } \\
\left.S=36.3 \mathrm{PSU} \text { (measurements st. } \mathrm{IN}_{1}\right) \\
\left.\left[\mathrm{O}_{2}\right]=229.8 \mu \mathrm{M} \text { (measurements st. } \mathrm{IN}_{1}\right) \\
\left.\left[\mathrm{NH}_{4}^{+}\right]=9.85 \mu \mathrm{M} \text { (measurements st. } \mathrm{IN}_{1}\right) \\
\left.\left[\mathrm{NO}_{3}^{-}\right]=2.5 \mu \mathrm{M} \text { (Solidoro et al., } 2009\right) \\
\left.\left[\mathrm{SO}_{4}^{2-}\right]=28.8 \mathrm{mM} \text { (measurements st. } \mathrm{IN}_{1}\right)\end{array}$ \\
\hline $\begin{array}{l}\text { Mineralisation (total organic carbon): } \\
\text { Total: } 11.1 \mathrm{mmol} \mathrm{C}^{-2} \mathrm{~d}^{-1} \\
\text { Degraded by } \mathrm{O}_{2}: 27 \% \\
\text { Degraded by } \mathrm{NO}_{3}^{-}: 1 \% \\
\text { Degraded by } \mathrm{SO}_{4}^{2-}: 71 \%\end{array}$ & $\begin{array}{l}\text { Mineralisation (total organic carbon): } \\
18.7 \text { mmol } \mathrm{C} \mathrm{m}^{-2} \mathrm{~d}^{-1} \\
\text { Degraded by } \mathrm{O}_{2}: 30 \% \\
\text { Degraded by } \mathrm{NO}_{3}^{-}: 2 \% \\
\text { Degraded by } \mathrm{SO}_{4}^{2-}: 68 \%\end{array}$ \\
\hline
\end{tabular}

organic matter mineralisation, $8 \%$ by nitrification, and $41 \%$ by reduced compounds oxidation.

\section{Discussion}

\subsection{Constraining POC fluxes}

Callier et al. (2006) measured biodeposits' production from farmed Mytilus edulis belonging to distinct age classes $(0+$, $1+)$, reporting values of 29.1 and $44.4 \mathrm{mg}$ ind. ${ }^{-1} \mathrm{~d}^{-1}$ for mussels of 4.0 and $6.9 \mathrm{~cm}$ respectively. Considering mus- sel density and farm geometry in our case study $\left(2 \mathrm{~km}^{2}\right.$; 15 ind. $\mathrm{m}^{-2} ; 25$ lines), these values correspond to fluxes of 3.5 to $5.3 \mathrm{~kg} \mathrm{C}$ line $\mathrm{e}^{-1} \mathrm{~d}^{-1}(10 \% \mathrm{C}$ in biodeposits - Brigolin et al., 2009), which are slightly lower than but comparable to our predictions - we found median values for faeces which range up to $10 \mathrm{~kg} \mathrm{C}$ line $\mathrm{k}^{-1} \mathrm{~d}^{-1}$.

The extent of the depositional area obtained in this study (on average $50 \mathrm{~m}$ from the edge of the farm; $14 \mathrm{~m}$ depth; mean current velocity of $5.4 \mathrm{~cm} \mathrm{~s}^{-1}$ ) can be compared with the results obtained in previous studies. In an exposed site, Weise et al. (2009) (Cascapedia Bay, Canada; $20 \mathrm{~m}$ depth; 

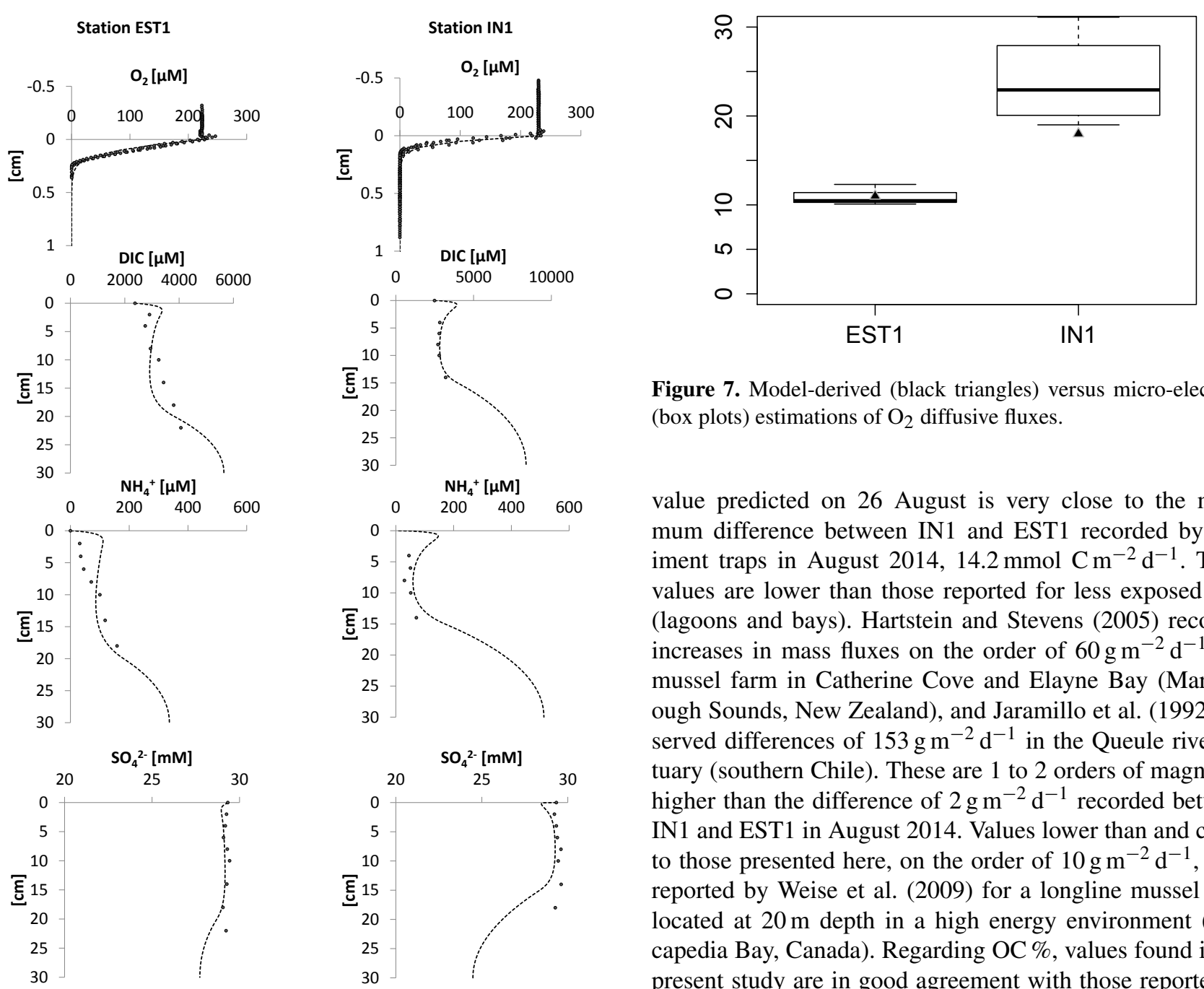

Figure 7. Model-derived (black triangles) versus micro-electrode (box plots) estimations of $\mathrm{O}_{2}$ diffusive fluxes.

value predicted on 26 August is very close to the maximum difference between IN1 and EST1 recorded by sediment traps in August 2014, $14.2 \mathrm{mmol} \mathrm{C} \mathrm{m}^{-2} \mathrm{~d}^{-1}$. These values are lower than those reported for less exposed sites (lagoons and bays). Hartstein and Stevens (2005) recorded increases in mass fluxes on the order of $60 \mathrm{~g} \mathrm{~m}^{-2} \mathrm{~d}^{-1}$ at a mussel farm in Catherine Cove and Elayne Bay (Marlborough Sounds, New Zealand), and Jaramillo et al. (1992) observed differences of $153 \mathrm{~g} \mathrm{~m}^{-2} \mathrm{~d}^{-1}$ in the Queule river estuary (southern Chile). These are 1 to 2 orders of magnitude higher than the difference of $2 \mathrm{~g} \mathrm{~m}^{-2} \mathrm{~d}^{-1}$ recorded between IN1 and EST1 in August 2014. Values lower than and closer to those presented here, on the order of $10 \mathrm{~g} \mathrm{~m}^{-2} \mathrm{~d}^{-1}$, were reported by Weise et al. (2009) for a longline mussel farm located at $20 \mathrm{~m}$ depth in a high energy environment (Cascapedia Bay, Canada). Regarding OC \%, values found in the present study are in good agreement with those reported by Hartstein and Stevens (2005) (5.82-6.56\%). OC \% found in the area of study $(4.23-6.34 \%)$ falls within the range reported by Giani et al. (2001) in different locations of the northern Adriatic Sea (1.05-21.81\%). Also, background total mass fluxes measured in the present work are comparable with data measured with sediment traps by the same aumean current velocity of $10 \mathrm{~cm} \mathrm{~s}^{-1}$ ), constrained the area of higher organic enrichment within $90 \mathrm{~m}$ from the edge of the farm. The dispersal area reported by Hatstein and Stevens (2005) was smaller, extending with a radius of approximately $30-40 \mathrm{~m}$ from the edge of the farm $(20-30 \mathrm{~m}$ depth; mean current velocity of $3.4-4.0 \mathrm{~cm} \mathrm{~s}^{-1}$ ). These differences in extent of the dispersal areas seem to be primarily associated with the action of currents and wave energy inducing resuspension of biodeposits accumulated on the seabed (Cromey et al., 2002). Magnitudes of OC fluxes predicted by the model were corroborated by the two sediment traps. Simulated biodeposition fluxes of $2.5 \mathrm{mmol} \mathrm{C} \mathrm{m}^{-2} \mathrm{~d}^{-1}$ on 10 September, at the beginning of the cycle, agree well with the very limited and not statistically valid POC flux difference (IN-EST) between average trap measurements at the same time $\left(3.3 \mathrm{mmol} \mathrm{C} \mathrm{m}^{-2} \mathrm{~d}^{-1}\right)$. The $13.3 \mathrm{mmol} \mathrm{C} \mathrm{m}^{-2} \mathrm{~d}^{-1}$ thors, who reported fluxes of $5.8 \mathrm{~g} \mathrm{~m}^{-2} \mathrm{~d}^{-1}$ (total mass flux) at an offshore station located in the northern Adriatic Sea and mean fluxes of approximately $30.0 \mathrm{~g} \mathrm{~m}^{-2} \mathrm{~d}^{-1}$ in prodelta areas of Po and Adige rivers, with high annual variability (range 0.08-240 $\mathrm{g} \mathrm{m}^{-2} \mathrm{~d}^{-1}$ ). Relatively low background values obtained in our study can be associated with lower annual discharge $\left(10.9 \mathrm{~m}^{3} \mathrm{~s}^{-1}\right)$ of the Sile River than of Adige and Brenta (respectively 139.5 and $85.9 \mathrm{~m}^{3} \mathrm{~s}^{-1}-1994-2008$ averages from Cozzi and Giani, 2011), being characterised by a particularly low value of the discharge rate in August and September (ARPAV, 2010) with respect to other months. In summary, the predicted fluxes agree well with sediment trap data, and mass fluxes measured by traps are close to values reported for similar environments, being markedly lower than those recorded in lower energy environments. 

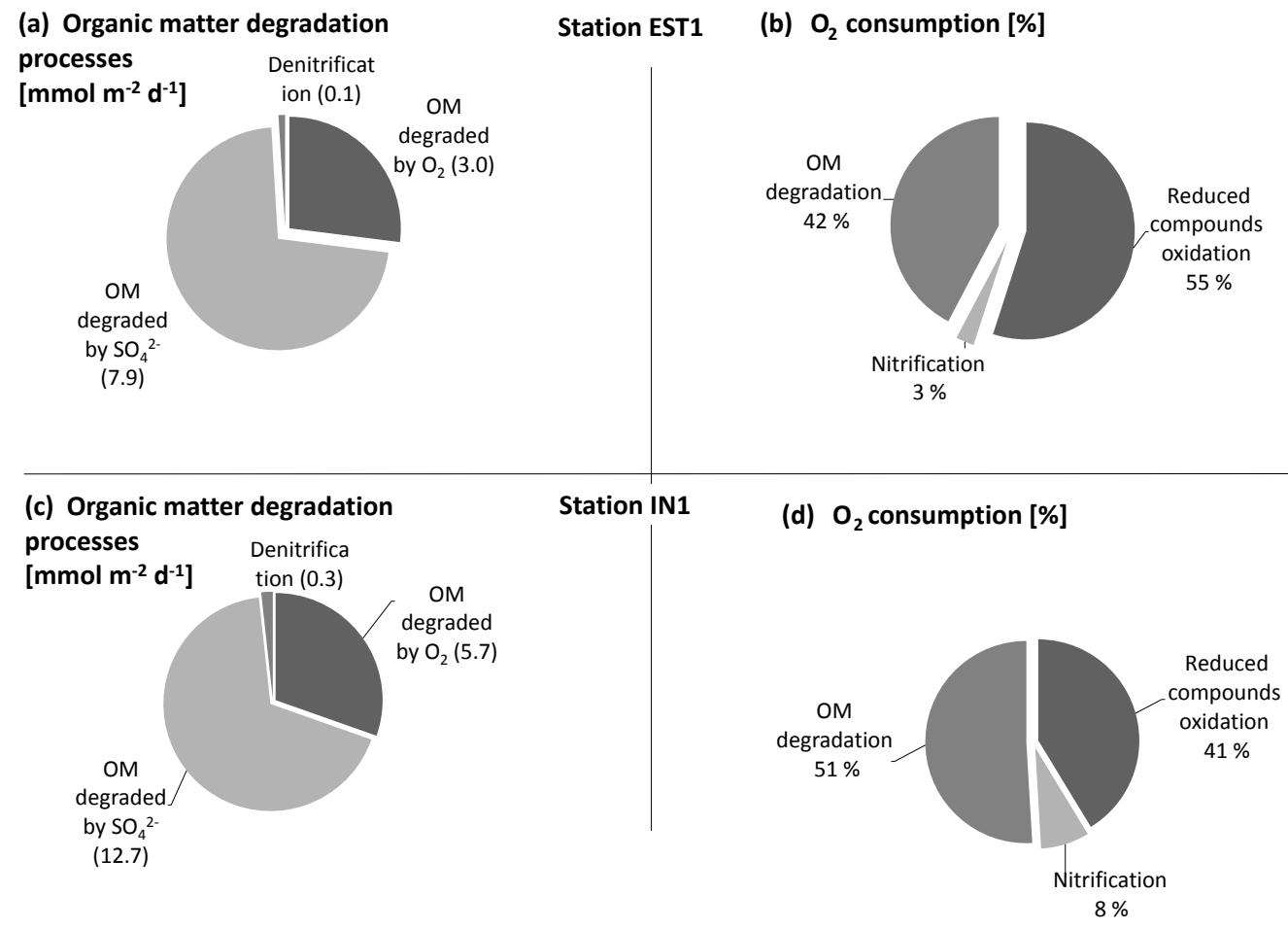

Figure 8. Model estimations: relative importance of different pathways on the total organic matter at EST1 (a) and IN1 (c); ratios of different redox pathways to total oxygen consumption at EST1 (b) and IN1 (d).

\subsection{Influences of perturbed POC fluxes on organic matter mineralisation in sediments}

Absolute values of the POC fluxes obtained from the sediment trap experiments can be cross-compared with the values estimated through the inverse use of the EDM. The value of $11.6 \mathrm{mmol} \mathrm{C} \mathrm{m}^{-2} \mathrm{~d}^{-1}$ at EST1 accounts for approximately $50 \%$ of the flux measured from the traps ( $22 \mathrm{mmol} \mathrm{C}^{-2} \mathrm{~d}^{-1}$ on average). This difference can be primarily related to the fact that the EDM accounts only for reactive $\mathrm{C}$, while the sediment trap captures all types of $\mathrm{C}$, including the inert fraction. On top of this, traps only provided a snapshot of the deposition in August and September - disregarding the seasonal variability in this deposition and the presence of pulse deposition events. Finally, it is worth remarking that resuspension is a common mechanism in shelf trap measurements: in the northern Adriatic Giani et al. (2001) estimated the contribution of resuspension to the gross flux sedimented in traps reaching $43.7 \%$.

Dedieu et al. (2007) compared seasonal cycles of C, N, and $\mathrm{O}$ inside and outside a shellfish farming area in a lagoon located in southern France, by combining a steady state diagenetic model (Soetaert et al., 1996) with a comprehensive set of experimental data. Model results showed that organic matter accumulation in the farming area enhanced the anaerobic metabolism. Oxygen microprofiles recorded by Dedieu et al. (2007) inside and outside the mussel farm presented differences which are comparable to those recorded in the present work, with a decrease of $50 \%$ in oxygen penetration depth, and an increase up to 3 times of diffusive $\mathrm{O}_{2}$ fluxes $\left(30 \mathrm{mmol} \mathrm{O}_{2} \mathrm{~m}^{-2} \mathrm{~d}^{-1}\right.$ versus $90 \mathrm{mmol} \mathrm{O}_{2} \mathrm{~m}^{-2} \mathrm{~d}^{-1}$ ). In Dedieu et al. (2007) this was accompanied by a remarkable enhancement in $\mathrm{NH}_{4}^{+}$concentrations, which was not visible in the field data reported in the present study. This can certainly be related to the difference in the rate of biodeposit accumulation, although other factors can also play a role (changes of local macrobenthic activity and of coupled nitrification-denitrification rates). Mean OC fluxes estimated by Dedieu et al. (2007) by calibrating the diagenesis model at the mussel farm site were $38.4,108.0$, and $108.0 \mathrm{mmol} \mathrm{C} \mathrm{m}^{-2} \mathrm{~d}^{-1}$, respectively in winter, spring, and summer, with increases by $26.4,53.4$, and $52.4 \mathrm{mmol} \mathrm{C} \mathrm{m}^{-2} \mathrm{~d}^{-1}$ with respect to a station of reference located outside of the farm influence, in the respective seasons. In our work, the background flux (OM1 + OM2 flux at EST1) was lower, $11.6 \mathrm{mmol} \mathrm{C} \mathrm{m}^{-2} \mathrm{~d}^{-1}$, with an increase of $8.2 \mathrm{mmol} \mathrm{C} \mathrm{m}^{-2}$ underneath the farm, at IN1. The relative increase, with respect to the background flux, was $71 \%$, which is comparable to the $69 \%$ increase found by Dedieu et al. (2007) in winter. Nonetheless, in absolute terms, Dedieu et al. (2007) reported a difference of approximately $50 \mathrm{mmol} \mathrm{C} \mathrm{m}^{-2} \mathrm{~d}^{-1}$ in summer, in a system already characterised by large fluxes of organic matter, and hence dominated by $\mathrm{SO}_{4}^{2-}$ reduction, whereas in this study, the in- 
crease is 5 times less $-10 \mathrm{mmol} \mathrm{Cm}^{-2} \mathrm{~d}^{-1}$, over a system which has mostly oxic and suboxic diagenesis. Difference in absolute values of OC fluxes can be related to a higher mussel stocking density (production in the Thau lagoon is 2333 versus $1450 \mathrm{t} \mathrm{km}^{-2}$ at the farm in Jesolo), a lower depth (7 m Thau lagoon, $14 \mathrm{~m}$ Jesolo), and the hydrodynamic regime of the site (lagoon environment with low energetics in term of hydrodynamics - current meter records not available from the study). In our case, even if the relative change of POC flux between the mussel farm and the reference is large, it does not affect the porewater composition significantly at depth. We cannot rule out spatial heterogeneity within each station, which would smooth the difference between IN1 and EST1. However, the fact that $\mathrm{O}_{2}$ fluxes reflect the increased input by the mussels points towards internal mechanisms that regulate porewater composition. The shape of the DIC- $\mathrm{NH}_{4}^{+}$ profiles indicates bioirrigation (Meile et al, 2001; Canavan et al., 2006), although the deeper increase is not visible in our data profiles due to limited penetration of the cores. Indeed, the very limited increase in concentration profiles in the first centimetres can only be linked to the input of bottom water with lower DIC and $\mathrm{NH}_{4}^{+}$by irrigation, given the large recycling intensity in surface sediments as exemplified by the $\mathrm{O}_{2}$ profile. Therefore, one way to explain the lack of differences between the IN1 and EST1 porewater composition is to relate it to changes in the bioirrigation profiles at the two stations. We remark here that $\alpha_{0}$ and xirr $_{1}$ were the only two parameters calibrated at IN1, and they suggest a higher infauna activity, shifted towards the surface at this site. This feature was independently confirmed by a set of macrobenthos samples collected at the two stations as a part of a complementary study (Colla, 2017). Macrobenthos samples showed a higher diversity (48 versus 31 taxa recorded) and abundance (on average 1900 versus 1000 ind. $\mathrm{m}^{-2}$ ) at IN1 with respect to EST1, accompanied by the presence of larger organisms $\left(0.065 \mathrm{~g}_{\text {ind. }}{ }^{-1}\right.$ at IN1 versus $0.034 \mathrm{~g}$ ind. ${ }^{-1}$ at EST1). This is in agreement with the expected influence of biodeposition from mussel culture (McKindsey et al., 2011). Species recognised as important bioturbators (such as Lagis koreni, Glycera unicornis, Sipunculus nudus, Eunice vittata, Hilbigneris gracilis, Amphiura chiajei, Ensis minor, Dosinia lupinus, Tellina distorta, and Nassarius incrassatus) were present in both samples, accounting for approximately $18 \%$ of the total abundance at EST1 and for 35\% at IN1. Calibrated values of $\alpha_{0}\left(20 \mathrm{yr}^{-1}\right.$ at EST1 and $40 \mathrm{yr}^{-1}$ at IN1) are close to those estimated by Meile et al. (2001) for Buzzards Bay site, $30-60 \mathrm{yr}^{-1}$ (water depth $15 \mathrm{~m}$ ), and slightly higher than those estimated by Canavan et al. (2006) through data fitting, $10 \mathrm{yr}^{-1}$ at a coastal freshwater lake (Haringvliet, in the Netherlands).

According to model estimations, total mineralisation at EST1 accounts for $96 \%$ of deposited OM (OM1 + OM2), with $0.5 \mathrm{mmol} \quad \mathrm{C} \mathrm{m}^{-2} \mathrm{~d}^{-1}$ escaping mineralisation through burial. This fraction decreases to $94 \%$ at IN1 (1.1 mmol $\mathrm{C} \mathrm{m}^{-2} \mathrm{~d}^{-1}$ of non-mineralised POC), where the model is run under transient conditions. The relative contribution of different mineralisation pathways to the total OM degradation is comparable to that reported by Pastor et al. (2011) for stations with comparable OM fluxes in the Rhône River prodelta and shelf area. At stations undergoing organic carbon deposition ranging between 7.3 and $16.2 \mathrm{mmol} \mathrm{C} \mathrm{m}^{-2} \mathrm{~d}^{-1}$ (their stations L, I, C, J, F), these authors found oxic mineralisation ranging between 44 and $67 \%$, nitrification between 1 and $6 \%$, and anoxic mineralisation between 27 and $51 \%$. The largest fraction of oxygen, $67-87 \%$, was consumed by OM degradation; nitrification consumed up to the $31 \%$ of the $\mathrm{O}_{2}$, while the re-oxidation of anaerobic products accounted for only $2.1 \%$ of oxygen consumption. This marks a difference with respect to the results obtained in the present work, since in our model a larger fraction of oxygen is consumed for reduced substances' oxidation (54\% at EST1 and $41 \%$ at IN1). This is also visible in Fig. 6, where relevant drops in $\mathrm{SO}_{4}^{2-}$ concentration are predicted by the model below the bioirrigated layer - approximately $2 \mathrm{mM}$ at EST1 and $5 \mathrm{mM}$ at IN1. The different behaviour may be due to the processes controlling $\mathrm{H}_{2} \mathrm{~S}$ and $\mathrm{Fe}$ in the study of Pastor et al. where most $\mathrm{H}_{2} \mathrm{~S}$ is precipitated as $\mathrm{FeS}_{2}$, thus escaping re-oxidation by sulfides. A more precise estimation of the fate of this oxygen could be obtained by introducing FeS precipitation in the model, for which at least $\mathrm{Fe}^{2+}$ measurements in porewater would be required.

The higher influx of oxygen and enhanced bioirrigation at the mussel site (IN1) reflected a substantial change in the pathways of oxygen consumption, with an increase of oxic degradation of OM2 and a relative decrease of oxygen demanded for reduced substances re-oxidation - this is clearly linked to the input of fresh OM from the mussels, which is mineralised aerobically. Nonetheless, due to the higher absolute fluxes of OM, the oxygen consumed by reduced substances' oxidation is higher at IN1, $7.4 \mathrm{mmol} \mathrm{O}_{2} \mathrm{~m}^{-2} \mathrm{~d}^{-1}$, than at EST1, $6.2 \mathrm{mmol} \mathrm{O} \mathrm{m}^{-2} \mathrm{~d}^{-1}$. Higher $\mathrm{NH}_{4}^{+}$concentration predicted at station EST1 with respect to field data could be explained with a higher rate of nitrification at this station. However, in the calibration performed within this work, the kinetic constant for nitrification was kept at its original value (Table A4), due to the lack of data concerning $\mathrm{NO}_{3}^{-}$. Our model results indicated that denitrification contributed between 1 and $2 \%$ to the total mineralisation, which is comparable to previous estimations in the Mediterranean Sea near the Rhone River (Pastor et al., 2011; 0.1-4\%) and in the northern Adriatic, 2-4\% (Capet, unpublished data) and slightly lower than what is estimated for the Black Sea (Capet et al., 2016; 5-6\%).

\subsection{Integrated model features}

The pelagic deposition model allowed the extent of the deposition area to be simulated, as well as its variability with time. Being integrated with a daily time step, the Mediterranean 
mussel population dynamic model allows the non-linear effects of the different environmental variables and physiological processes acting on deposition (i.e. water temperature, chlorophyll $a$ concentration, allometric dependence of the clearance rate on body size) to be combined instantaneously and allows these effects to be integrated on the timescale of the farming cycle. The combination of the bioenergeticsbased population model, which allows organic matter production from the lines to be estimated, and the deposition model accounts for particles' dispersion and represents a novel aspect of the present work with respect to previous modelling studies on mussel deposition. The modelling study by Hartstein and Stevens (2005) applied a sensitivity approach to study the organic deposition of Perna canaliculus in New Zealand, comparing sites characterised by different hydrodynamic exposure and assuming an arbitrary particle release rate. Weise et al. (2009) modelled mussel biodeposition at different sites on the eastern coast of Canada, imposing organic wastage from the farm lines as model input, on the basis of site-specific field measurements (Callier et al., 2006) and extrapolation from other sites. It is worth remarking here that the integration of growth and deposition models can represent a resources which allows the model to be applied at different sites in which environmental variables are known, without the need of performing in situ estimations of biodeposits' production. On top of this, the model could be used to explore the effect of climate-change-induced longterm trends of variation in water temperature and particulate organic matter concentrations, which are expected to have an influence on mussel growth performances (Cochrane et al., 2009; Rosa et al., 2012). We underline that the application presented in this work could be extended in order to include the evaluation of the uncertainties related to spatial inconsistencies of nearshore-offshore remote sensing products.

\section{Conclusions}

The combined application of an early diagenesis model and of a model of POC production and deposition from shellfish filter feeders allowed the differences induced on sediment biogeochemistry to be studied quantitatively by a local perturbation of the natural POC downward flux. This is one of the few existing attempts to couple pelagic mussel production models with early diagenetic models in order to investigate the effects of a local gradient of disturbance on coastal sediments' biogeochemistry and benthic-pelagic coupling (review by Paraska et al., 2014). Model-predicted POC fluxes showed marked spatial and temporal variability. Sediment trap data at the two sampled stations were in agreement with model results. The increase of POC fluxes by $100 \%$ caused by the mussel farm induced visible effects on sediment biogeochemistry. Measured oxygen microprofiles showed a remarkable decrease in oxygen penetration depth, approximately $50 \%$, accompanied by an increase in the $\mathrm{O}_{2}$ influx at the station characterised by higher POC. DIC and $\mathrm{NH}_{4}^{+}$concentrations showed similar behaviour, with a more obvious effect of bioirrigation underneath the farm. Indeed, the early diagenesis model calibration led to an estimation of enhanced and shallower bioirrigation underneath the farm which were confirmed by independent data on macrofauna composition collected at the study site. We remark that, based on the number of cores available, it was not possible to quantitatively assess the uncertainty related to these coefficients, of which estimation would allow bioirrigation to be better characterised in this area. Early diagenesis model results indicated a similar proportion between oxic and anoxic degradation pathways at the two stations, with an increase in the absolute values of oxygen consumed by OM degradation and reduced substances re-oxidation underneath the mussel farm. The model estimates an area of $159000 \mathrm{~m}^{2}$ (approx $8 \%$ of the farm lease) characterised by deposition fluxes $\geq 8 \mathrm{mmol} \mathrm{C} \mathrm{m}^{-2} \mathrm{~d}^{-1}\left(\approx 0.1 \mathrm{~g} \mathrm{C} \mathrm{m}^{-2} \mathrm{~d}^{-1}\right)$. An enhancement of $\mathrm{O}_{2}$ influx induced by the farm - with respect to a non-farmed area of the same dimension ranges from $4.6 \times 10^{5} \mathrm{~mol} \mathrm{O}_{2} \mathrm{yr}^{-1}$ (via EDM estimation) to $7.2 \times 10^{5} \mathrm{~mol} \mathrm{O}_{2} \mathrm{yr}^{-1}$ (calculated from profiles). These results can help in the assessment of the role of disturbance gradients, such as an increased POC flux, in affecting sediment biogeochemical conditions and spatial habitat heterogeneity. From an applied perspective, knowledge and representation of these processes is fundamental to attempt a sound management of the marine space in those coastal ecosystems in which mussel farming is extensively practised.

Data availability. Data are publically available from SEANOE at https://doi.org/10.17882/53945 (Brigolin et al., 2018). 
Appendix A
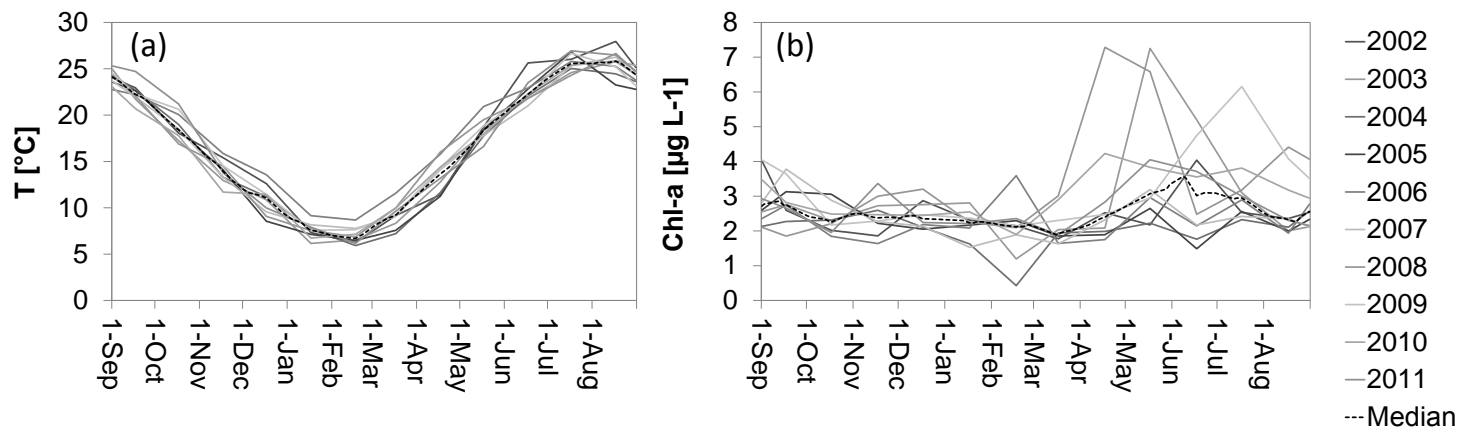

Figure A1. Model forcings: (a) sea water temperature, (b) chlorophyll $a$ concentration. Time series for years 2002-2011 and the overall medians are reported.
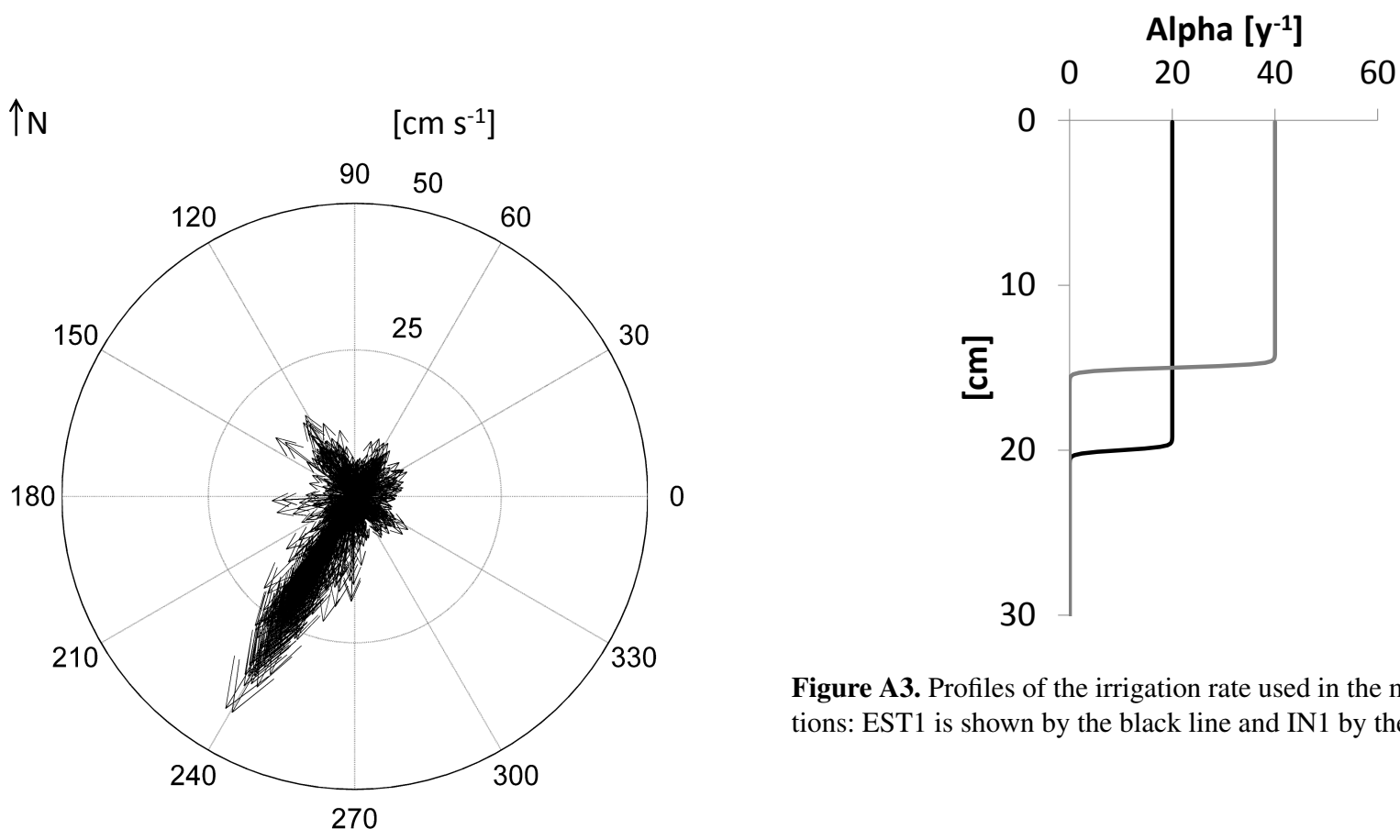

Figure A3. Profiles of the irrigation rate used in the model applications: EST1 is shown by the black line and IN1 by the grey line.

Figure A2. Module $\left(\mathrm{cm} \mathrm{s}^{-1}\right)$ and directions of the water currents as recorded nearby the farm between March and September 2010. 
Table A1. Parameters used in the deposition model.

\begin{tabular}{|c|c|c|c|c|}
\hline Name & Description & Value & Units & Reference \\
\hline $\mathrm{d} x, \mathrm{~d} y$ & Horizontal resolution & 20 & $(\mathrm{~m})$ & - \\
\hline $\mathrm{d} t$ & Time step & 60 & (s) & - \\
\hline$K_{x}, K_{y}$ & $\begin{array}{l}\text { Horizontal eddy diffusivity } \\
\text { coefficient }\end{array}$ & 0.1 & $\left(\mathrm{~m}^{2} \mathrm{~s}^{-1}\right)$ & $\begin{array}{l}\text { Cromey et al. (2002), } \\
\text { Jusup et al. (2007) }\end{array}$ \\
\hline$K_{z}$ & $\begin{array}{l}\text { Vertical eddy diffusivity } \\
\text { coefficient }\end{array}$ & 0.001 & $\left(\mathrm{~m}^{2} \mathrm{~s}^{-1}\right)$ & $\begin{array}{l}\text { Cromey et al. (2002), } \\
\text { Jusup et al. (2007) }\end{array}$ \\
\hline$w_{\mathrm{f}}$ & $\begin{array}{l}\text { Normal distribution of settling } \\
\text { velocity of faeces }\end{array}$ & $\mu=1.0 ; \sigma=0.1$ & $\left(\mathrm{~cm} \mathrm{~s}^{-1}\right)$ & Weise et al. (2009) \\
\hline$w_{\mathrm{p}}$ & $\begin{array}{l}\text { Normal distribution of settling } \\
\text { velocity of pseudofaeces }\end{array}$ & $\mu=0.1 ; \sigma=0.01$ & $\left(\mathrm{~cm} \mathrm{~s}^{-1}\right)$ & Weise et al. (2009) \\
\hline
\end{tabular}

Table A2. Reaction network implemented in the EDM model. Equations (1) and (2): $C_{\mathrm{S}}$ and $C_{\mathrm{W}}$ are, respectively, the concentration of solid and dissolved species; $t$ denotes the time, $z$ denotes the depth below the sediment-water interface, $\varphi$ is the sediment porosity, $D$ is the total molecular diffusion plus bioturbation, $D_{\mathrm{b}}, \omega$ is the sedimentation rate, and $\Sigma R$ represents the net rate of concentration change due to chemical and biological sources and sinks. The advection term includes burial and compaction; the diffusion term includes molecular and ionic diffusion, as well as bioturbation. The network is a simplified version of the one proposed by Van Cappellen and Wang (1996). Reactions (1)-(3) are implemented separately for each OM fraction.

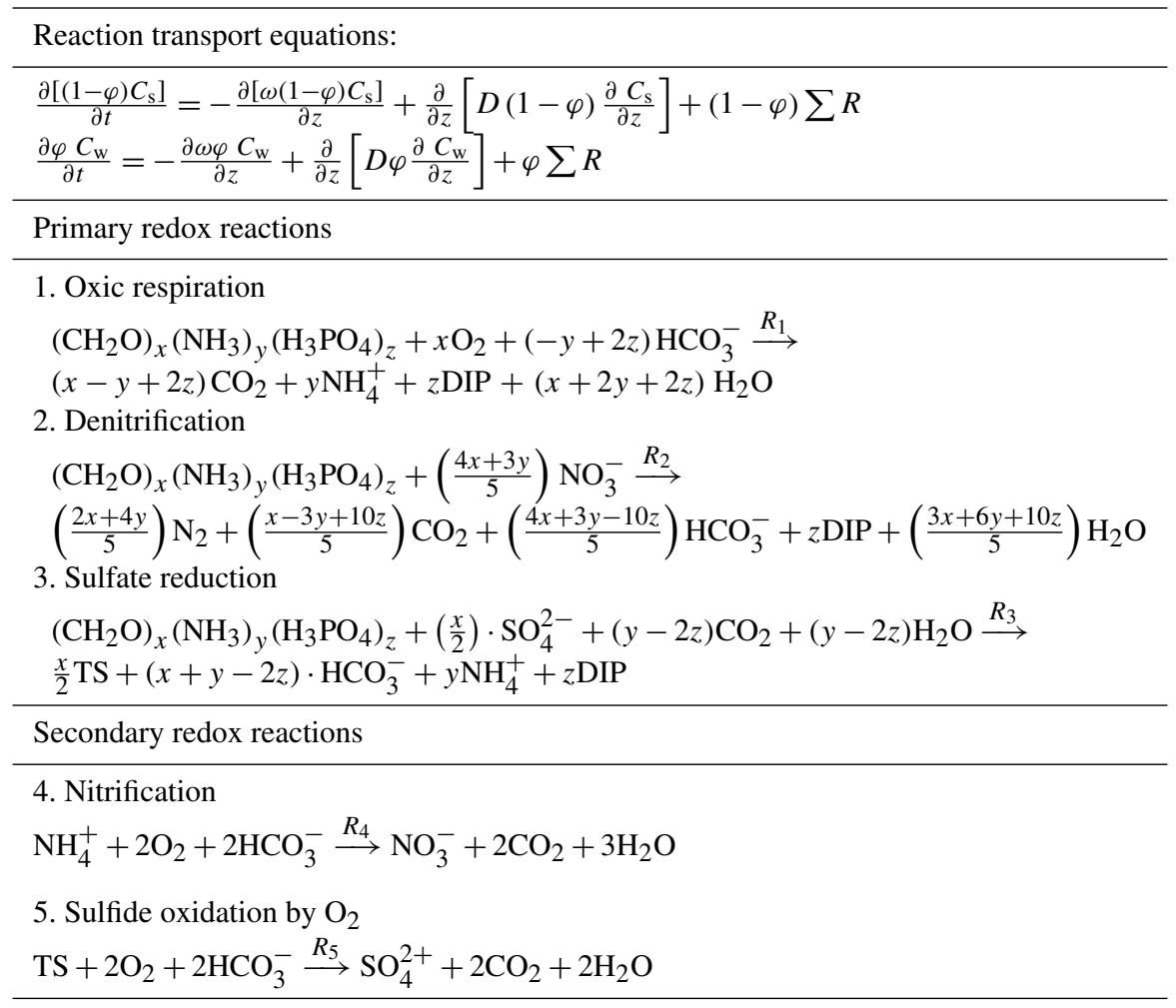


Table A3. Rate laws used in the EDM. Rates refer to the reactions listed in Table A2. The $f_{i}$ values were computed according to the formulation reported in Aguilera et al. (2005).

\begin{tabular}{ll}
\hline Rate laws \\
\hline$R_{1}=f_{\mathrm{O}_{2}} \cdot k_{\mathrm{OM}_{k}} \cdot\left[\mathrm{OM}_{k}\right] \cdot k_{\text {acc }}$, with $k=1,2,3$ \\
$R_{2}=f_{\mathrm{NO}_{3}^{-}} \cdot k_{\mathrm{OM}_{k}} \cdot\left[\mathrm{OM}_{k}\right] \cdot k_{\mathrm{acc}}$, with $k=1,2,3$ \\
$R_{3}=f_{\mathrm{SO}_{4}} \cdot k_{\mathrm{OM}_{k}} \cdot\left[\mathrm{OM}_{k}\right]$, with $k=1,2,3$ \\
$R_{4}=k_{4} \cdot\left[\mathrm{NH}_{4}^{+}\right] \cdot\left[\mathrm{O}_{2}\right]$ \\
$R_{5}=k_{5} \cdot[\mathrm{TS}] \cdot\left[\mathrm{O}_{2}\right]$ \\
\hline
\end{tabular}

Table A4. Reaction-specific and general parameters used in the EDM. (1 refers to Wang and Van Cappellen (1996); 2 refers to Jourabchi et al. (2005); 3 refers to Canavan et al. (2006); 4 refers to Berg et al. (2003).)

\begin{tabular}{|c|c|c|c|c|}
\hline Parameter name & Value & Units & Description & Source \\
\hline $\mathrm{O}_{2 \lim }$ & $16.0 \times 10^{-6}$ & $\mathrm{~mol} \mathrm{~L}^{-1}$ & $\begin{array}{l}\text { Limiting concentration } \\
\text { for } \mathrm{O}_{2}\end{array}$ & Mean value from $1,2,3,4$ \\
\hline $\mathrm{NO}_{3 \lim }^{-}$ & $4.7 \times 10^{-6}$ & $\mathrm{~mol} \mathrm{~L}^{-1}$ & $\begin{array}{l}\text { Limiting concentration } \\
\text { for } \mathrm{NO}_{3}^{-}\end{array}$ & Mean value from $1,2,3,4$ \\
\hline $\mathrm{SO}_{4 \lim }^{2-}$ & $1180.0 \times 10^{-6}$ & $\operatorname{mol~L}^{-1}$ & $\begin{array}{l}\text { Limiting concentration } \\
\text { for } \mathrm{SO}_{4}^{2-}\end{array}$ & Mean value from $1,2,3$ \\
\hline$k_{4}$ & $1.2 \times 10^{7}$ & $\left(\mathrm{~mol} \mathrm{~L}^{-1}\right)^{-1} \mathrm{yr}^{-1}$ & $\begin{array}{l}\text { Kinetic constant for } \\
\text { nitrification }\end{array}$ & Mean value from $1,2,3,4$ \\
\hline \multirow[t]{5}{*}{$K_{5}$} & $2.7 \times 10^{8}$ & $\left(\mathrm{~mol} \mathrm{~L}^{-1}\right)^{-1} \mathrm{yr}^{-1}$ & $\begin{array}{l}\text { Kinetic constant for } \\
\text { sulfides' oxidation by } \\
\mathrm{O}_{2} \text { kinetic constant }\end{array}$ & Mean value from 1, 2, 3, 4 \\
\hline & 0.25 & $\mathrm{~cm} \mathrm{yr}^{-1}$ & Vertical velocity & Alvisi and Frignani (1996) \\
\hline & $10^{-4}$ & year & Time step & - \\
\hline & 30 & $\mathrm{~cm}$ & Max. depth modelled & - \\
\hline & 601 & - & Grid nodes & - \\
\hline
\end{tabular}


Competing interests. The authors declare that they have no conflict of interest.

Acknowledgements. Daniele Brigolin was supported by an individual mobility grant from the University of Venice $\mathrm{Ca}$ ' Foscari (IRIDE-DHAMACO project). Model runs were performed in SCSCF (www.dais.unive.it/scscf), a multiprocessor cluster system owned by $\mathrm{Ca}$ ' Foscari University of Venice running under GNU/Linux. We gratefully acknowledge Gaël Monvoisin from GEOPS France for the assistance in the analyses, Alfredo Boldrin from CNR for giving access to the current meter data, and Nautica Dal Vì for providing space for setting up lab facilities. We would like to thank the two anonymous reviewers for their constructive comments on the initial version of this manuscript.

Edited by: Silvio Pantoja

Reviewed by: two anonymous referees

\section{References}

Aguilera, D. R., Jourabchi, P., Spiteri, C., and Regnier, P.: A knowledge-based reactive transport approach for the simulation of biogeochemical dynamics in Earth systems, Geochem. Geophy. Geosy., 6, Q07012, https://doi.org/10.1029/2004GC000899, 2005.

Andrews, D. and Bennet, A.: Measurements of diffusivity near the sediment-water interface with a fine-scale resistivity probe, Geochim. Cosmochim. Ac., 45, 2169-2175, 1981.

Arndt, S., Jørgensen, B. B., Larowe, D. E., Middelburg, J. J., Pancost, R. D., and Regnier, P.: Quantifying the degradation of organic matter in marine sediments: a review and synthesis, Earth Sci. Rev., 123, 53e86, https://doi.org/10.1016/j.earscirev.2013.02.008, 2013.

ARPAV: Agenzia Regionale per la Prevenzione e Protezione Ambientale del Veneto, Relazione no. 10/10, MISURE DI PORTATA ESEGUITE DA ARPAV NEGLI ANNI 2008-2009, 36 pp., 2010.

Bacher, C. and Gangnery, A.: Use of dynamic energy budget and individual based models to simulate the dynamics of cultivated oyster populations, J. Sea Res., 56, 140-156, 2006.

Barrington, K., Chopin, T., and Robinson, S.: Integrated multitrophic aquaculture (IMTA) in marine temperate waters, in: Integrated mariculture: a global review, edited by: Soto, D., FAO Fisheries and Aquaculture Technical Paper, No. 529, Rome, FAO, 7-46, 2009.

Berg, P., Rysgaard, S., and Thamdrup, B.: Dynamic modeling of early diagenesis and nutrient cycling: a case study in an arctic marine sediment, Am. J. Sci., 303, 905-955, 2003.

Berner, R. A.: Early diagenesis: A Theoretical Approach. Princeton University Press, Princeton, NJ, 1980.

Boudreau, B. P.: Diagenetic Models and Their Implementation: Modeling Transport and Reactions in Aquatic Sediments, Springer, New York, 414 pp., 1997.

Brigolin, D., Dal Maschio, G., Rampazzo, F., Giani, M., and Pastres, R.: An Individual-Based population dynamic model for estimating biomass yield and nutrient fluxes through an off-shore
Mytilus galloprovincialis farm, Estuar. Coast. Shelf S., 82, 365376, 2009.

Brigolin, D., Lovato, T., Rubino, A., and Pastres, R.: Coupling early-diagenesis and pelagic biogeochemical models for estimating the seasonal variability of $\mathrm{N}$ and $\mathrm{P}$ fluxes at the sedimentwater interface: application to the North Western Adriatic coastal zone, J. Marine Syst., 87, 239-255, 2011.

Brigolin, D., Meccia, V. L., Venier, C., Tomassetti, P., Porrello, S., and Pastres, R.: Modelling the interactions between offshore fish cages and elemental biogeochemical cycles in the Mediterranean sea, Aquacult. Env. Interact., 5, 71-88, 2014.

Brigolin, D., Rabouille, C., Bombled, B., Colla, S., Vizzini, S., Pastres, R., and Pranovi, F.: Biogeochemical data at a Mediterranean mussel farm, Northern Adriatic Sea, SEANOE, https://doi.org/10.17882/53945, 2018.

Burdige, D. J.: Geochemistry of marine sediments. Princeton University Press, Princeton, NJ, 2006.

Callier, M. D., Weise, A., McKindsey, C. W., and Desrosiers, G.: Sedimentation rates in a suspended mussel farm (Great-Entry Lagoon, Canada): biodeposit production and dispersion, Mar. Ecol. Prog. Ser., 322, 129-141, 2006.

Canavan, R. W., Slomp, C. P., Jourabchi, P., Van Cappellen, P., Laverman, A. M., and van den Berg, G. A.: Organic matter mineralization in sediment of a coastal freshwater lake and response to salinization, Geochim. Cosmochim. Ac., 70, 28362855, 2006.

Cannizzaro, J. P. and Carder, K. L.: Estimating chlorophyll $a$ concentrations from remote-sensing reflectance in optically shallow waters, Remote Sens. Environ., 101, 13-24, 2006.

Capet, A., Meysman, F. J. R., Akoumianaki, I., Soetaert, K., and Grégoire, M.: Integrating sediment biogeochemistry into 3D oceanic models: A study of benthic-pelagic coupling in the Black Sea, Ocean Model., 101, 83-100, 2016.

Chamberlain, J.: Modelling the environmental impacts of suspended mussel (Mytilus edulis L.) farming, PhD thesis, Napier University, Edinburgh, 2002.

Christensen, P. B., Glud, R. N., Dalsgaard, T., and Gillespie, P.: Impacts of longline mussel farming on oxygen and nitrogen dynamics and biological communities of coastal sediments, Aquaculture, 218, 567-588, 2003.

Cochrane, K., De Young, C., Soto, D., and Bahri, T.: Climate change implications for fisheries and aquaculture: overview of current scientific knowledge, FAO Fisheries and Aquaculture Technical Paper, No. 530, Rome, FAO., 212 pp., 2009.

Colla, S.: Structure and functioning of the Northern Adriatic coastal ecosystem, within the context of the Marine Strategy Framework implementation. $\mathrm{PhD}$ thesis, Università Ca' Foscari Venezia, 140 pp., 2017.

Cozzi, S. and Giani, M.: River water and nutrient discharges in the Northern Adriatic Sea: Current importance and long term changes, Cont. Shelf Res., 31, 1881-1893, 2011.

Cranford, P. J., Strain, P. M., Dowd, M., Hargrave, B. T., Grant, J., and Archambault, M. C.: Influence of mussel aquaculture on nitrogen dynamics in a nutrient enriched coastal embayment, Mar. Ecol. Prog. Ser., 347, 61-78, 2007.

Cromey, C. J., Nickell, T. D., and Black, K. D.: DEPOMOD - modelling the deposition and biological effects of waste solids from marine cage farms, Aquaculture, 214, 211-239, 2002. 
Dahlbäck, B. and Gunnarson, L. A. H.: Sedimentation and sulfate reduction under a mussel culture, Mar. Biol., 63, 269-275, 1981.

Dale, A. W., Regnier, P., Knab, N. J., Jørgensen, B. B., and Van Cappellen, P.: Anaerobic oxidation of methane (AOM) in marine sediments from the Skagerrak (Denmark): II. Reaction-transport modeling, Geochim. Cosmochim. Ac., 72, 2880-2894, 2008.

Dedieu, K., Rabouille, C., Gilbert, F., Soetaert, K., Metzger, E., Simonucci, C., Jézéquel, D., Prévot, F., Anschutz, P., Hulth, S., Ogier, S., and Mesnage, V.: Coupling of carbon, nitrogen and oxygen cycles in sediments from a Mediterranean lagoon: a seasonal perspective, Mar. Ecol. Progr. Ser., 346, 45-59, 2007.

Filgueira, R., Comeau, L. A., Landry, T., Grant, J., Guyondet, T., and Mallet, A.: Bivalve condition index as an indicator of aquaculture intensity: A meta-analysis, Ecol. Indic., 25, 215-229, 2013.

Giani, M., Boldrin, A., Matteucci, G., Frascari, F., Gismondi, M., and Rabitti, S.: Downward fluxes of particulate carbon, nitrogen and phosphorus in the north-western Adriatic Sea, Sci. Total Environ., 266, 125-134, 2001.

Giovanardi, O., Cornello, M., Tiozzo, K., Casale, M., and Franceschini, G.: Effetti degli aggregati mucillaginosi sulle comunità macrozoobentoniche al largo di Chioggia, Programma di monitoraggio e studio sui Processi di formazione delle Mucillagini nell'Adriatico e nel Tirreno (MAT) Rapporto finale vol. II, ICRAM, Roma, 351-366, 2003.

Grasshof, K., Ehrhardt, M., and Kremling, K.: Methods of Seawater Analysis, second revised and extended edition, Verlag Chemie $\mathrm{GmbH}, 1983$.

Hartstein, N. D. and Stevens, C. L.: Deposition beneath long-line mussel farms, Aquacult. Eng., 33, 192-213, 2005.

Hatcher, A., Grant, J., and Schofield, B.: Effects of suspended mussel culture (Mytilus spp.) on sedimentation, benthic respiration and sediment nutrient dynamics in a coastal bay, Mar. Ecol. Prog. Ser., 115, 219-235, 1994.

Jaramillo, E., Bertran, C., and Bravo, A.: Mussel biodeposition in an estuary in southern Chile, Mar. Ecol. Prog. Ser., 82, 85-94, 1992.

Jourabchi, P., van Cappellen, P., and Regnier, P.: Quantitative interpretation of $\mathrm{pH}$ distributions in aquatic sediments: a reaction transport modeling approach, Am. J. Sci., 305, 919-956, 2005.

Jusup, M., Gecek, S., and Legović, T.: Impact of aquacultures on the marine ecosystem: modelling benthic carbon loading over variable depth, Ecol. Model., 200, 459-466, 2007.

Jusup, M., Klanjšček, J., Petricioli, D., and Legović, T.: Predicting aquaculture-derived benthic organic enrichment: model validation, Ecol. Model., 220, 2407-2414, 2009.

Mauri, E., Poulain, P.-M., and Južnič-Zonta, Z.: MODIS chlorophyll variability in the northern Adriatic Sea and relationship with forcing parameters, J. Geophys. Res., 112, C03S11, https://doi.org/10.1029/2006JC003545, 2007.

McKindsey, C. W., Archambault, P., Callier, M. D., and Olivier, F.: Influence of suspended and off-bottom mussel culture on the sea bottom and benthic habitats: a review, Can. J. Zool., 89, 622-646, 2011.

Meile, C., Koretsky, C. M., and Van Cappellen, P.: Quantifying bioirrigation in aquatic sediments: An inverse modeling approach, Limnol. Oceanogr., 6, 164-177, 2001.

Mesnage, V., Ogier, S., Bally, G., Disnar, J.-R., Lottier, N., Dedieu, K., Rabouille, C., and Copard, Y.: Nutrient dynamics at the sediment-water interface in a Mediterranean lagoon (Thau, France): Influence of biodeposition by shellfish farming activities, Mar. Environ. Res., 63, 257-277, 2007.

MiPAAF: Piano Strategico per l'acquacoltura in Italia, 2014-2020, Direzione Generale della Pesca e dell'Acquacoltura PEMAC, 282 pp., 2014.

Mirto, S., La Rosa, T., Danovaro, R., and Mazzola, A.: Microbial and meiofaunal response to intensive mussel-farm biodeposition in coastal sediments of the western Mediterranean., Mar. Pollut. Bull., 40, 244-252, 2000.

Mugnai, C., Gerino, M., Frignani, M., Sauvage, S., and Bellocci, L. G.: Bioturbation experiments in the Venice Lagoon, Hydrobiologia, 494, 245-250, 2003.

Nizzoli, D., Welsh, D. T., Bartoli, M., and Viaroli, P.: Impacts of mussel (Mytilus galloprovincialis) farming on oxygen consumption and nutrient recycling in a eutrophic coastal lagoon, Hydrobiologia, 550, 183-198, 2005.

Paraska, D. W., Hipsey, M. R., and Salmon, S. U.: Sediment diagenesis models: Review of approaches, challenges and opportunities, Environ. Modell. Softw., 61, 297-325, 2015.

Pastor, L., Cathalot, C., Deflandre, B., Viollier, E., Soetaert, K., Meysman, F. J. R., Ulses, C., Metzger, E., and Rabouille, C.: Modeling biogeochemical processes in sediments from the Rhône River prodelta area (NW Mediterranean Sea), Biogeosciences, 8, 1351-1366, https://doi.org/10.5194/bg-8-13512011, 2011.

Pawlowicz, R., Beardsley, B., and Lentz, S.: Classical tidal harmonic analysis including error estimates in MATLAB using $\mathrm{T}$ TIDE, Comput. Geosci.-UK, 28, 929-937, 2002.

Press, W. H., Flannery, B. P., Teukolsky, S. A., and Vetterling, W. T.: Numerical Recipes, the Art of Scientific Computing, Cambridge University Press, 818 pp., 1987.

Rampazzo, F., Berto, D., Giani, M., Brigolin, D., Covelli, S., Cacciatore, F., Boscolo, R., Bellucci, L. G., and Pastres, R.: Impact of mussel farm biodeposition on sediment biogeochemistry in the north-west Adriatic Sea, Estuar. Coast. Shelf S., 129, 49-58, 2013.

Rassmann, J., Lansard, B., Pozzato, L., and Rabouille, C.: Carbonate chemistry in sediment porewaters of the Rhône River delta driven by early diagenesis (northwestern Mediterranean), Biogeosciences, 13, 5379-5394, https://doi.org/10.5194/bg-135379-2016, 2016.

Regnier, P., O'Kane, J. P., Steefel, C. I., and Vanderborght, J. P.: Modeling complex multi-component reactive-transport systems: Towards a simulation environment based on the concept of a Knowledge Base, Appl. Math. Model., 26, 913-927, 2002.

Rooney, N., McCaan, K. S., and Moore, J. C.: A landscape theory for food web architecture, Ecol. Lett., 11, 867-881, 2008.

Rosa, R., Marques, A., and Nunes, M. L.: Impact of climate change in Mediterranean aquaculture, Rev. Aquacult., 4, 163-177, 2012.

Sarà, G., Palmeri, V., Rinaldi, A. , Montalto, V., and Helmuth, B.: Predicting biological invasions in marine habitats through eco-physiological mechanistic models: a case study with the bivalve Brachidontes pharaonis, Diversity Distrib., 19, 12351247, 2013.

Seeberg-Elverfeldt, J., Schlüter, M., Feseker, T., and Kölling, M.: Rhizon sampling of porewaters near the sediment-water interface of aquatic systems, Limnol. Oceanogr.-Meth., 3, 361-371, 2005. 
Snelgrove, P. V. R., Thrush, S. F., Wall, D. H., and Norkko, A.: Real world biodiversity-ecosystem functioning: a seafloor perspective, Trends Ecol. Evol., 29, 398-405, 2014.

Soetaert, K., Herman, P. M. J., and Middelburg, J. J.: A model of early diagenetic processes from the shelf to abyssal depths, Geochim. Cosmochim. Act., 60, 1019-1040, 1996.

Solidoro, C., Bastianini, M., Bandelj,V., Codermatz, R., Cossarini, G., Melaku Canu, D., Ravagnan, E., Salon, S., and Trevisani, S.: Current state, scales of variability, and trends of biogeochemical properties in the northern Adriatic Sea, J. Geophys. Res., 114, C07S91, https://doi.org/10.1029/2008JC004838, 2009.

Stenon-Dozey, J. M. E., Jackson, L. F., and Busby, A. J.: Impact of mussel culture on macrobenthic community stucture in Saldanha Bay, South Africa, Mar. Pollut. Bull., 39, 37-366, 1999.

Tenore, K. R. and Dunstan, W. M.: Comparison of feeding and biodeposition of three bivalves at different food levels, Mar. Biol., 21, 190-195, 1973.

Thomas, Y., Mazurieì, J., Alunno-Bruscia, M., Bacher, C., Bouget, J.F., Gohin, F., Pouvreau, S., and Struski, C.: Modelling spatiotemporal variability of Mytilus edulis (L.) growth by forcing a dynamic energy budget model with satellite-derived environmental data, J. Sea Res., 66, 308-317, 2011.
Van Cappellen, P. and Wang, Y. F.: Cycling of iron and manganese in surface sediments: a general theory for the coupled transport and reaction of carbon, oxygen, nitrogen, sulfur, iron, and manganese, Am. J. Sci., 296, 197-243, 1996.

Villnäs, A., Norkko, J., Hietanen, S., Josefson, A. B., Lukkari, K., and Norkko, A.: The role of recurrent disturbances for ecosystem multifunctionality, Ecology, 94, 2275-2287, 2013.

Volkenborn, N., Meile, C., Polerecky, L., Wethey, D. S., Woodin, S. A., Pilditch, C., Norkko, A., Norkko, J., Hewitt, J. E., and Thrush, S. F.: Intermittent bioirrigation and oxygen dynamics in permeable sediments: An experimental and modeling study of three tellinid bivalves, J. Mar. Res., 70, 794-823, 2012.

Weise, A. M., Cromey, C. J., Callier, M., Archambault, P., Chamberlain, J., and McKindsey, C. W.: Shellfish-DEPOMOD: Modelling the biodeposition from suspended shellfish aquaculture and assessing benthic effects, Aquaculture, 288, 239-253, 2009.

Westrich, J. T. and Berner, R. A.: The role of sedimentary organic matter in bacterial sulfate reduction: the G-model tested, Limnol. Oceanogr., 29, 236-249, 1984. 